\title{
Statistical analysis of long term spatial and temporal trends of temperature parameters over Sutlej river basin, India
}

\author{
Dharmaveer Singh ${ }^{1}$, R D Glupta ${ }^{1,2, *}$ and Sanjay K Jain ${ }^{3}$ \\ ${ }^{1}$ GIS Cell, Motilal Nehru National Institute of Technology, Allahabad 211 004, India. \\ ${ }^{2}$ Department of Civil Engineering, Motilal Nehru National Institute of Technology, Allahabad 211 004, India. \\ ${ }^{3}$ Water Resources Systems Division, National Institute of Hydrology, Roorkee 247 667, India. \\ ${ }^{*}$ Corresponding author. e-mail: gupta.rdg@gmail.com
}

The annual and seasonal trend analysis of different surface temperature parameters (average, maximum, minimum and diurnal temperature range) has been done for historical (1971-2005) and future periods (2011-2099) in the middle catchment of Sutlej river basin, India. The future time series of temperature data has been generated through statistical downscaling from large scale predictors of CGCM3 and HadCM3 models under A2 scenario. Modified Mann-Kendall test and Cumulative Sum (CUSUM) chart have been used for detecting trend and sequential shift in time series of temperature parameters. The results of annual trend analysis for period of 1971-2005 show increasing as well as decreasing trends in average $\left(T_{\text {Mean }}\right)$, maximum $\left(T_{\text {Max }}\right)$, minimum $\left(T_{\text {Min }}\right)$ temperature and increasing trends in Diurnal Temperature Range (DTR) at different stations. But the annual trend analysis of downscaled data has revealed statistically significant (95\% confidence level) rising trends in $T_{\text {Mean }}, T_{\text {Max }}, T_{\text {Min }}$ and falling trend in DTR for the period 2011-2099. The decreasing trend in DTR is due to higher rate of increase in $T_{\text {Min }}$ compared to $T_{\mathrm{Max}}$.

\section{Introduction}

The Himalayan mountain range consists of the youngest and loftiest mountain chains in the world. It stretches over $3000 \mathrm{~km}$ from the Pamir in west to the Purvanchal in east and is arcuate in shape. It covers a vast area of $\sim 750,000 \mathrm{~km}^{2}$ that mainly consists of northern Pakistan, Nepal, Bhutan and the northwestern and northeastern states of India. The region is characterized by a variety of climatic conditions varying from tropical to polar. The Himalayan glaciers, the source of many major river systems (Indus, Ganga, Brahmaputra) are exposed to climate change as snow accumulation and snowmelt processes are greatly dependent on temperature and precipitation (Immerzeel et al. 2010). This region has been described as a hot spot of climate change because of the fact that perturbation occurring due to increased temperature have shown greater impacts on hydrologic system here than elsewhere in the world (Kulkarni et al. 2013).

The studies of Intergovernmental Panel on Climate Change (IPCC) have revealed rise in surface mean annual temperature over Himalayan region in the 20th century (IPCC 2007). The warming rate has been found higher than the global average $\left(0.74^{\circ} \mathrm{C} \pm 0.18 / 100\right.$ year $)$. It is not uniform either spatially or temporally over the Himalayan region. A positive relationship between altitude and warming rate has been observed over the Greater

Keywords. Temperature; CGCM3; HadCM3; modified Mann-Kendall test; statistical analysis; Sutlej basin. 
Himalayan region (New et al. 2002). Shrestha et al. (1999) have also analyzed maximum temperature data from 49 stations in Nepal for the period 1971-1994. Further, this study has revealed increase in trend of mean maximum temperature in most of the Middle Mountain and Himalayan regions ranging from $0.06^{\circ} \mathrm{C} /$ year to $0.12^{\circ} \mathrm{C} /$ year, whereas this has been found less than $0.03^{\circ} \mathrm{C} /$ year in Terai (southern plains) regions. Similar patterns in warming have also been reported over Indian Himalayan region (Borgaonkar et al. 1996; Sharma et al. 2000). A rise of about $1.6^{\circ} \mathrm{C}$ in mean annual temperature over northwestern Himalayan region by the end of last century has also been reported by Bhutiyani et al. (2007). This rapid warming has accelerated rate of retreat in the Himalayan glaciers. It is predicted that at this present rate of retreat, glaciers in the region will vanish within 40 years and the flow of Himalayan rivers will reduce drastically, resulting in widespread water shortages (WWF Nepal Program 2005).

The energy exchange processes over the earth's surface can be explained precisely through surface temperature. So, it is considered as an important signal of state of climate (Bhutiyani et al. 2007). The historical records as well as modelled values of temperature can be used to evaluate the patterns of behaviour that the climate has exhibited in the past and will show in the future in order to determine whether recent climate behaviours are normal or anomalous ( $\mathrm{Xu}$ et al. 2008). A proper assessment of likely future temperature and its variability is to be made for various climate scenarios so that its impact on hydrological processes and water resources can be studied (Anandhi et al. 2009). The future time series of temperature data can be generated from Global Climate Models (GCMs). However, GCM simulations offer information at coarse spatial resolution and direct applications of their outputs in climate change impact studies at regional and local scales have shown poor results. An alternative option is to downscale GCM's climate output. In downscaling, large-scale climate information are applied to predict local metrological conditions (Maurer and Hidalgo 2008; Wilby and Dawson 2013). The techniques of downscaling are grouped into two categories; dynamical and statistical (Ghosh 2010).

In statistical downscaling (SD), a statistical/ empirical relationship is established between GCMs simulated large scale atmospheric variables (predictors) such as specific humidity, temperature, geo-potential height, etc., with station (local)scale meteorological variables (predictands) such as temperature and precipitation (Kim et al. 1984). Based on these statistical/empirical relationships, local scale predictands such as temperature can be downscaled at specific site or station. SD has shown advantage over dynamical downscaling (DD) approach as it is faster and simpler in use, less computationally expensive and applicable for uncertainty and risk analyses (Wilby et al. 2000; Yarnal et al. 2001). However, the requirement of long time series of historical weather stations data is a serious drawback of this approach (Mahmood and Babel 2013). SD approach has been classified into three subcategories; weather typing, weather generator, and regression/transform function. The strength and weakness of each approach has been reviewed in more detail by various authors (Hewitson and Crane 1996; Wilby and Wigley 1997; Wilby et al. 2002; Fowler et al. 2007).

A limited number of studies on temperature trends has been performed over the Indus basin particularly in the Sutlej basin. This has been attributed to inaccessibility and scarcity of well distributed meteorological stations and nonavailability of past records of temperature data in the basin. The basin is sensitive to climate change and increase in mean annual temperature has been found in lower and middle elevation ranges of the basin (Jain et al. 2009). It has been concluded from the studies that future increase in temperature would bring significant change in seasonal distribution of stream flow. Reductions in stream flow have been expected in summer season and increase in spring season. The decrease in stream flow during summer season may have repercussions on water supply, irrigation, and hydropower production in the basin. However, studies on recent temperature trends over the region are still lacking.

The increased regional significance of Sutlej river basin has motivated the present study. The main objectives of the study are: (1) to analyze temporal and spatial trends in average $\left(T_{\text {Mean }}\right)$, maximum $\left(T_{\text {Max }}\right)$, minimum $\left(T_{\text {Min }}\right)$ temperature, and Diurnal Temperature Range (DTR) from 1971-2005 (historical) and 2011-2099 (future period) in a part of Sutlej river basin (NW Himalayan region), India; (2) statistical downscaling and future projection of $T_{\mathrm{Max}}$ and $T_{\mathrm{Min}}$ from predictors of third generation Canadian Coupled Global Climate Model (CGCM3) and Hadley Centre Coupled Model, version 3 (HadCM3) under A2 scenario; (3) to quantify shift in thermal regime and discuss feasible causes of variation in $T_{\text {Mean }}, T_{\text {Max }}, T_{\text {Min }}$, and DTR. The remaining part of this paper has been arranged as follows: geographical settings have been described and shown in section 2 . The types of data and their sources have been discussed in section 3. Methodology has been elaborated in section 4. Results have been shown in section 5 . Finally, discussion of the results and conclusion drawn from this study have been presented in section 6 . 


\section{Geographical settings}

The study has been carried out in middle part of the Sutlej river basin. It is confined to the hilly state of Himachal Pradesh, India. The state shares its boundary with four Indian states namely, Jammu and Kashmir from north, Punjab from west, Haryana from south, Uttarakhand from south-east and has international border with China (Tibet). It has covered parts of Simla, Kullu, Mandi, Bilaspur, and Solan districts of Himachal Pradesh. This has a spread of $2457 \mathrm{~km}^{2}$ and lies between $31^{\circ} 05^{\prime} 00^{\prime \prime}$ and $31^{\circ} 39^{\prime} 26^{\prime \prime} \mathrm{N}$ latitudes and $76^{\circ} 51^{\prime} 11^{\prime \prime}$ and $77^{\circ} 45^{\prime} 17^{\prime \prime} \mathrm{E}$ longitudes (figure 1). The altitude in the basin ranges between 502 and $5128 \mathrm{~m}$. The elevation and slope aspects control temperature and also have strong impact on spatial and temporal distribution of precipitation in a mountainous region.

The major characteristics of prevailed climate in the basin have been illustrated in figure 2. The mean annual temperature and precipitation have been recorded as $21.23^{\circ} \mathrm{C}$ and $103 \mathrm{~cm}$ respectively. The mean monthly $T_{\text {Max }}$ varies between $18.59^{\circ}$ and $35.77^{\circ} \mathrm{C}$ and mean annual $T_{\text {Max }}$ is $28.26^{\circ} \mathrm{C}$. The mean monthly $T_{\text {Min }}$ ranges from $4.26^{\circ}$ to $22.81^{\circ} \mathrm{C}$. Sometimes temperature below $1^{\circ} \mathrm{C}$ is recorded in the study region. The hottest months are May and June with mean $T_{\mathrm{Max}}$ of around $35.5^{\circ} \mathrm{C}$. December and January are the coldest months with mean $T_{\text {Min }}$ of around $4.5^{\circ} \mathrm{C}$ and $5.5^{\circ} \mathrm{C}$. The diurnal

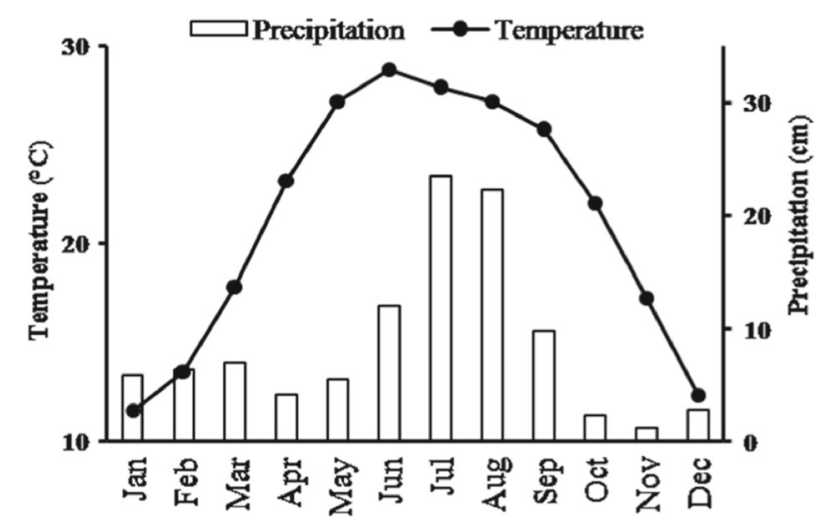

Figure 2. Climatic characteristics prevailed in the study area.

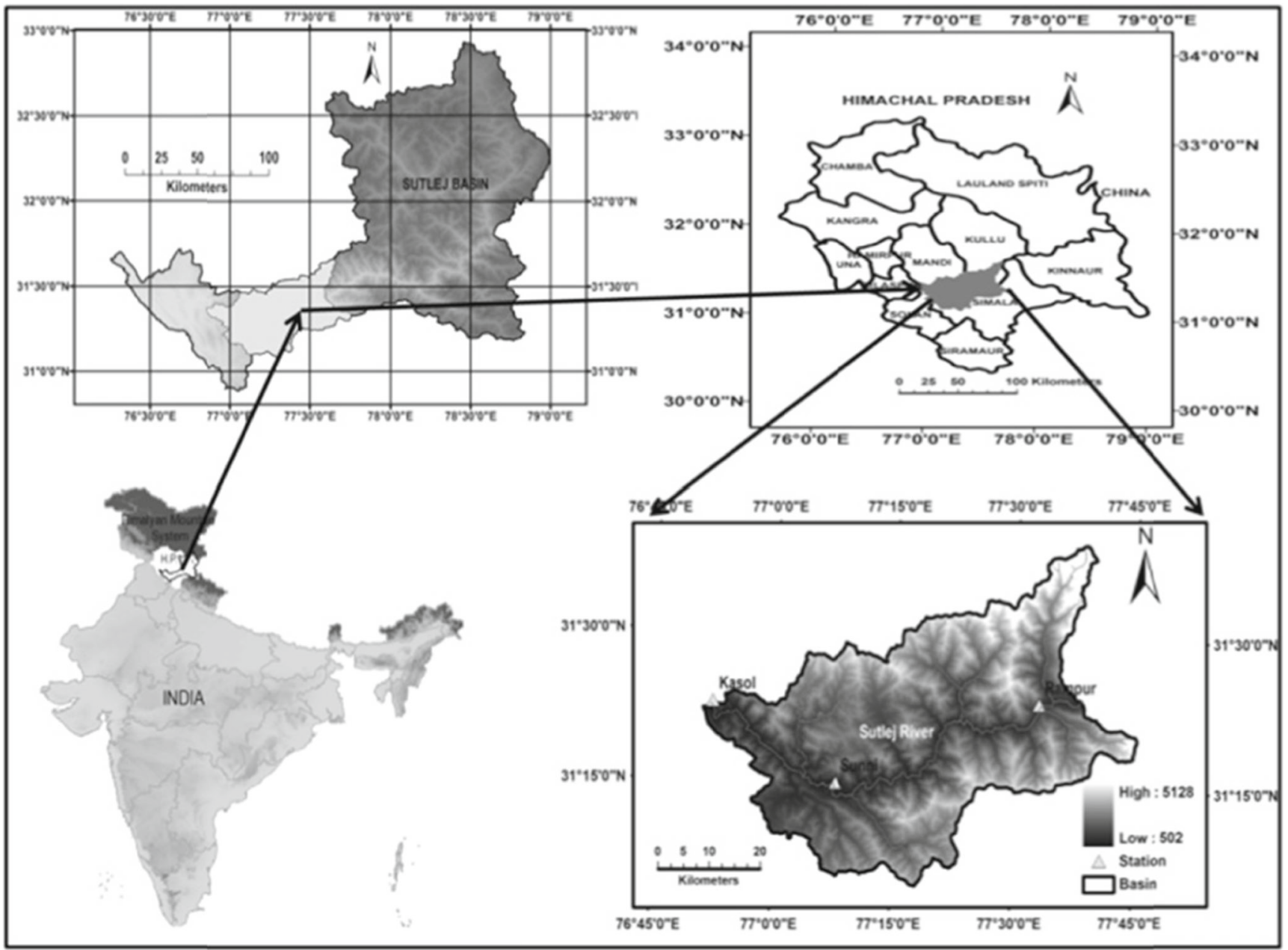

Figure 1. Location map of the study area. 
difference (on annual basis) between the $T_{\mathrm{Min}}$ and $T_{\text {Max }}$ is in the range of $4.5^{\circ}-16^{\circ} \mathrm{C}$.

The identified hydropower potential in this basin is $9226.75 \mathrm{MW}$. The major hydropower projects installed on the Sutlej river within the study area are Sunni Dam Project of 1080 MW, Rampur Hydroelectric Power Project (RHEP) of $412 \mathrm{MW}$, and Nathpa Jhakari Hydro-electric Power Project (NJHEP) of 1500 MW. They contribute to the economy of India by supplying water and electricity for agriculture and to various industrial sectors in the states of Himachal Pradesh, Punjab, Haryana and Rajasthan. Change in future climate will alter patterns of flow in river and could further affect water resources and hydroelectric power production. Therefore, the present study will provide useful insight to devise a better strategy for the management of water resources in the Sutlej basin.

\section{Datasets description}

\subsection{Data availability and sources}

The meteorological data used in the present study are: (1) long-term observed time series of $T_{\text {Mean }}$, $T_{\text {Max }}, T_{\text {Min }}$, and DTR data. $T_{\text {Mean }}$ is average of $T_{\text {Max }}$ and $T_{\mathrm{Min}}$ and DTR is derived by subtracting $T_{\mathrm{Min}}$ from $T_{\text {Max }}$ data; (2) the observed large scale predictors of National Centre for Environmental Prediction/ National Centre for Atmospheric Research (NCEP/ NCAR) reanalysis datasets; and (3) the modelled predictors of third-generation Canadian Coupled Global Climate Model (CGCM3) and Hadley Centre Coupled Model, version 3 (HadCM3) under A2 scenario. The selection of CGCM3 and HadCM3 is made on the basis of literature review and availability of data in SDSM compatible format. Further, these two models have been extensively used in statistical downscaling of climate variables over Indian subcontinent (Anandhi et al. 2008, 2009; Meenu et al. 2012; Mahmood and Babel 2013; Srinivas et al. 2013).

The observed records of daily $T_{\text {Max }}$ and $T_{\text {Min }}$ have been collected for three hydro-meteorological stations namely Kasol, Sunni, and Rampur from Bhakra Beas Management Board (BBMB). The details of stations have been described in table 1 . The gridded predictor variables of NCEP/NCAR,
CGCM3 and HadCM3 for the nearest grid in study area have been directly downloaded from the websites of Data Access Integration (DAI) (http://loki. qc.ec.gc.ca/DAI/predictors-e.html) and Canadian Climate Impacts Scenarios (CCIS) (http://www. cics.uvic.ca/scenarios/index.cgi) respectively. The predictors are simulated under historical GHG and aerosol concentration experiment (20C3M) as well as Special Report on Emission Scenarios (SRES) A2 for future run for CGCM3 model and HadCM3 model, respectively. A2 emission scenario represents a heterogeneous world characterized by high concentration of $\mathrm{CO}_{2}$ (850 ppm) gas and regionally oriented economic development. There is a probability of the highest rise in temperature compared with other scenarios. This is considered as the worst among the entire scenarios. The study has been performed to observe plausible future change in patterns of various temperature parameters under highest concentration of $\mathrm{CO}_{2}$ in the atmosphere.

The NCEP/NCAR reanalysis datasets are available on grid spacing of $1.9^{\circ}$ latitude $\times 1.9^{\circ}$ longitude whereas CGCM3 and HadCM3 modelled predictors (under A2 scenario) are available on grid resolution $3.75^{\circ}$ latitude $\times 3.75^{\circ}$ longitude and $2.5^{\circ}$ latitude $\times 3.75^{\circ}$ longitude respectively. The NCEP/NCAR reanalysis predictors have to be re-gridded to conform to the grid-spacing of CGCM3 and HadCM3 models. The re-gridded and standardized predictors are supplied within the zip file. The predictor variables are available for period 1961-2100 for CGCM-3 model, 19612099 for HadCM3 model and 1961-2001/2003 for NCEP/NCAR respectively. All the predictor variables are available on daily time step and these have been normalized over 1961-1990 period.

\subsection{Validation and screening of observed data}

These stations are installed at an altitude of varying height and physiographic conditions. The minimum linear distance between two nearest stations is approximately $25 \mathrm{~km}$ and maximum $72 \mathrm{~km}$ respectively. The limitations of well distributed stations within study area has necessitated performing homogeneity test with data of individual stations and other stations in order to ensure spatial and

Table 1. Location details of the stations considered for the study in Sutlej basin.

\begin{tabular}{|c|c|c|c|c|c|c|c|c|c|}
\hline \multirow[b]{2}{*}{ Station } & \multirow[b]{2}{*}{ Latitude } & \multirow[b]{2}{*}{ Longitude } & \multirow{2}{*}{$\begin{array}{l}\text { Elevation } \\
\qquad(\mathrm{m})\end{array}$} & \multicolumn{2}{|c|}{$\begin{array}{l}\text { Average annual } \\
\text { temperature }\left({ }^{\circ} \mathrm{C}\right)\end{array}$} & \multicolumn{2}{|c|}{$\begin{array}{c}\text { Standard } \\
\text { deviation }\left({ }^{\circ} \mathrm{C}\right)\end{array}$} & \multicolumn{2}{|c|}{$\begin{array}{l}\text { Coefficient of } \\
\text { variance }\left({ }^{\circ} \mathrm{C}\right)\end{array}$} \\
\hline & & & & $T_{\operatorname{Max}}$ & $T_{\text {Min }}$ & $\overline{T_{\operatorname{Max}}}$ & $T_{\mathrm{Min}}$ & $\overline{T_{\operatorname{Max}}}$ & $T_{\text {Min }}$ \\
\hline Kasol (1970-2005) & $31^{\circ} 21^{\prime} 25^{\prime \prime}$ & $76^{\circ} 52^{\prime} 42^{\prime \prime}$ & 662 & 28.55 & 16.79 & 0.90 & 0.57 & 0.03 & 0.03 \\
\hline Sunni (1970-2005) & $31^{\circ} 14^{\prime} 15^{\prime \prime}$ & $77^{\circ} 06^{\prime} 30^{\prime \prime}$ & 655 & 29.02 & 12.27 & 1.05 & 1.02 & 0.03 & 0.08 \\
\hline Rampur (1970-2005) & $31^{\circ} 27^{\prime} 15^{\prime \prime}$ & $77^{\circ} 38^{\prime} 40^{\prime \prime}$ & 976 & 27.17 & 13.66 & 1.22 & 0.53 & 0.04 & 0.03 \\
\hline
\end{tabular}


temporal compatibility in observations (Mutreja 1986; van der Made 1987). This has been done by adopting established meteorological techniques like double mass-curves, simple linear correlation and regression analyses (Bhutiyani et al. 2009). The plotted graphs of double mass-curves performed for the three stations with each other have shown straight lines (figure 3). This reveals high temporal and spatial uniformity in the interannual variability of temperature parameters at all three stations. Further, these results are supported by positive bivariate correlations (statistically significant at 95\% confidence level) in linear regressions. Thus, the data has been found to be of reasonably high quality and used in investigating long-term trends in different surface temperature parameters in middle catchment of the Sutlej river basin, India. For the analysis, daily values of $T_{\text {Mean }}, T_{\text {Max }}, T_{\text {Min }}$ and DTR are summed to obtain annual and seasonal values at each station.

The monthly data series of observed $T_{\text {Mean }}$, $T_{\text {Max }}, T_{\text {Min }}$ and DTR have been inspected at each station for all the years. The Grubbs method has been used for detecting outliers (Grubbs 1969). The suspicious values have been removed and replaced by normal ratio methods. Besides, to confirm whether the recorded values are outliers or true events, regression through the origin has been performed. The standardized temperature indices (STI) for different temperature data $\left(T_{\text {Mean }}, T_{\text {Max }}, T_{\text {Min }}\right.$ and DTR $)$ have been derived by subtracting their mean and dividing by their standard deviation averaged over the period 1971-2005 from the time series (Pant and Rupa Kumar 1997). In this way, annual and seasonal STI of $T_{\text {Mean }}$, $T_{\text {Max }}, T_{\text {Min }}$ and DTR have been computed for all three stations.

\section{Methodology}

\subsection{Nonparametric test methods}

Parametric, nonparametric, Bayesian, time series, and nonparametric with resampling approaches are generally used for performing trend analysis over time series data. In literature, the strength and weakness of each method has been discussed in detail (Sonali and Kumar 2013). The two nonparametric test methods; modified Mann-Kendall (MK) test and Cumulative Sum (CUSUM) chart have been used for detecting trend and sequential shift in time series of $T_{\mathrm{Max}}$ and $T_{\mathrm{Min}}$ in the study region.

\subsubsection{Mann-Kendall (MK) test}

MK test is a nonparametric rank based test and has been used widely for analyzing trend in hydrologic and climatologic variables (Mann 1945). It has an advantage over other tests as it is distributionfree and robust against outliers (Hess et al. 2001). It assumes that the time series under research
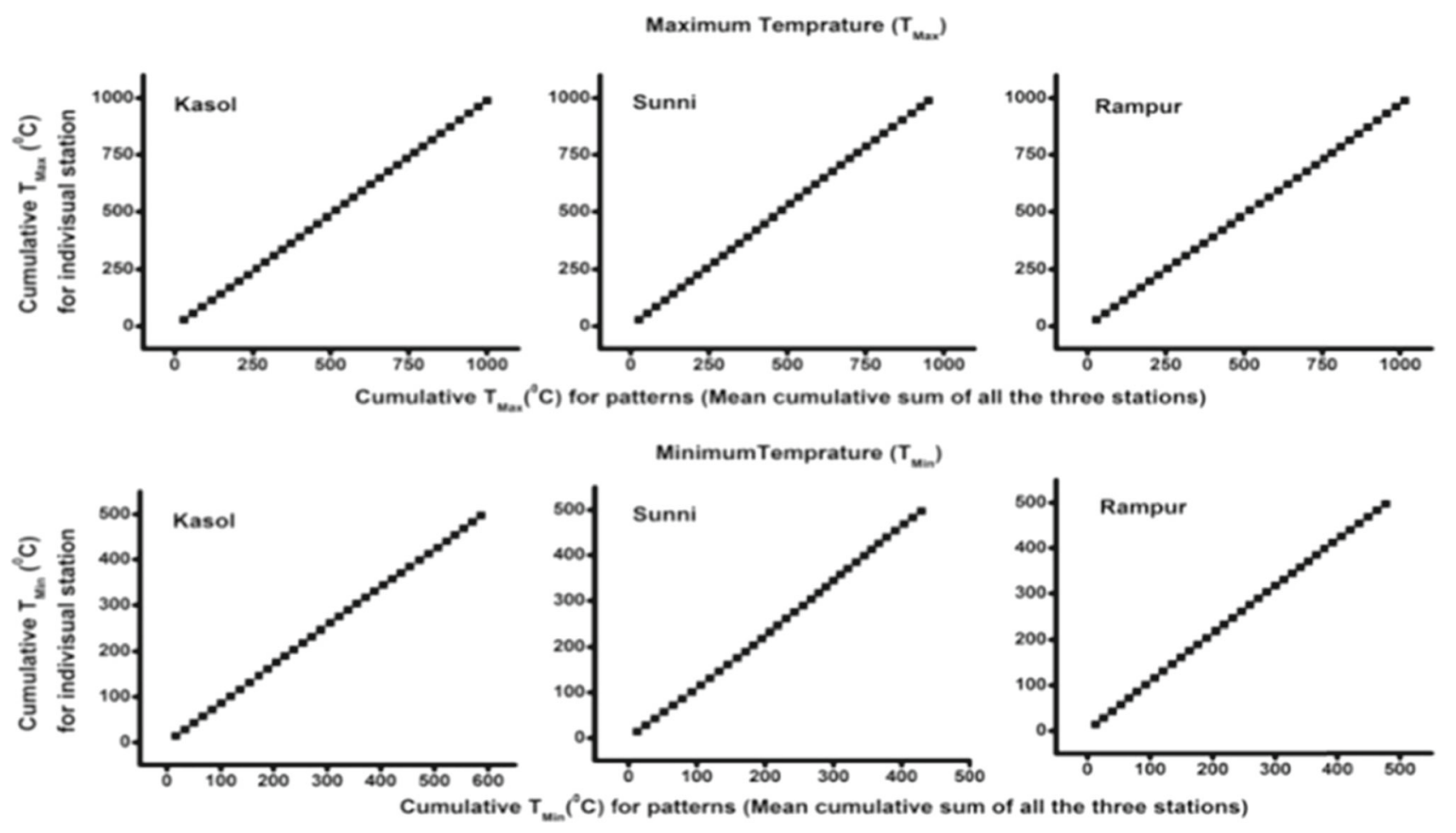

Figure 3. Homogeneity test of observed time series data ( $T_{\mathrm{Max}}$ and $\left.T_{\mathrm{Min}}\right)$ using double mass-curves method. 
are stable, independent, and random with equal probability distribution (Zhang et al. 2005).

In MK test, null hypothesis $\left(H_{0}\right)$ of no trend is checked with the alternative hypothesis $\left(H_{i}\right)$ of increasing or decreasing trend. The $S$ statistics of MK test is defined as (Mann 1945; Kendall 1975):

$$
S=\sum_{i=1}^{n-1} \sum_{j=i+1}^{n} \operatorname{sgn}\left(x_{j}-x_{i}\right)
$$

where $n$ is the number of data points, $x_{j}$ is the observed value at time $j$ and $x_{i}$ is the observed value at time $i$. The value of $\operatorname{sgn}\left(x_{j}-x_{i}\right)$ is computed as shown in equation 2 :

$$
\operatorname{sgn}\left(x_{j}-x_{i}\right)=\left\{\begin{aligned}
+1, & \left(x_{j}-x_{i}\right)>0 \\
0, & \left(x_{j}-x_{i}\right)=0 \\
-1, & \left(x_{j}-x_{i}\right)<0
\end{aligned}\right.
$$

For samples $(n \geq 10)$, MK test is conducted using a normal distribution and variance of $S$ statistic is defined by:

$$
\operatorname{Var}(S)=\frac{-\sum_{i=1}^{n} t_{i}(i)(i-1)(2 i+5)}{18}
$$

in which $t_{i}$ denotes the number of ties to extent $i$. The test statistic $Z$ is estimated as:

$$
Z= \begin{cases}\frac{S-1}{\sqrt{\operatorname{Var}(S)}}, & S>0 \\ 0, & S=0 \\ \frac{S+1}{\sqrt{\operatorname{Var}(S)}}, & S<0\end{cases}
$$

$H_{0}$ is rejected at $\alpha$ level of significance in a twosided test if the value of $|Z|$ is greater than $Z_{\alpha / 2}$ (Xu et al. 2008). The statistical interpretation of the rejection of $H_{0}$ at given $\alpha$ level of significance implies that a probability $\alpha$ trend is falsely identified. The significance level is taken as a criterion in hypothesis testing for rejection of $H_{0}$. The level of significance is a subjective issue and has been found between 1\% and 10\% level (mostly 5\% level) in several research studies (Patra et al. 2012). In this study, $H_{0}$ is tested at $5 \%$ level of significance $\left(Z_{0.025}=1.96\right)$.

MK test is applied to uncorrelated data because presence of serial correlation may increase or decrease probability of detecting significant trends (Helsel and Hirsch 1992; Kulkarni and von Storch 1995; Yue et al. 2002; Yue and Wang 2002; Yue and Pilon 2003). In case of serial correlation, correlation is computed between one time series and the same series lagged by one or more time units. The serial correlation coefficient $\left(\rho_{k}\right)$ which describes correlation between time series $x_{i}(i=1,2, \ldots, n-k)$ of first $(n-k)$ observations and last $(n-k)$ observations, i.e., $x_{i+k}(k=2,3, \ldots, n)$ is derived from the equation (5):

$$
\rho_{k}=\frac{\sum_{i=1}^{n-k}\left(x_{i}-\overline{x_{i}}\right)\left(x_{i}+k-\overline{x_{i}}+k\right)}{\left(\begin{array}{c}
{\left[\sum_{i=1}^{n-k}\left(x_{i}-\overline{x_{i}}\right)^{2}\right]^{1 / 2}} \\
\times\left[\sum_{i=1}^{n-k}\left(x_{i}+k-\overline{x_{i}}+k\right)^{2}\right]^{1 / 2}
\end{array}\right)}
$$

where $\bar{x}_{\mathrm{i}}$ is the mean of first $(n-k)$ observations and $\bar{x}_{i+k}$ is the mean of last $(n-k)$ observations. Generally, correlation coefficient lagged by 1 day (lag-1) is used for detecting serial correlation structure within time series as physical systems dependence on past values is likely to be strongest for the most recent past (Cunderlik and Burn 2004). The null hypothesis $\left(H_{0}: \rho_{1}=0\right)$ of serial independence is tested against alternative hypothesis $\left(H_{i}:\left|\rho_{1}\right|>0\right)$ using equation (6):

$$
t=\left|\rho_{1}\right| \sqrt{\frac{n-2}{1-\rho_{1}}}
$$

where test statistic $t$ has a Student's $t$-distribution with $n-2$ degrees of freedom. If $|t|>t_{\alpha / 2}$, the null hypothesis about serial independence is rejected at significance level $\alpha$.

Pre-whitening is being used for detecting a trend in a time series in the presence of serial correlation (Cunderlik and Burn 2002). Nonetheless, prewhitening is stated to reduce the rate of detection of significant trend in the MK test (Yue et al. 2002). To take this into account, Hamed and Rao (1998) proposed a modified MK test for serially correlated data based on a correction of the variance $(S)$ for the effective number of observations. The corrected variance $(S)$ is given by:

$$
\operatorname{Var}(S)=\frac{[n(n-1)(2 n+5)]}{18} \frac{n}{n^{*}}
$$

where

$$
\begin{aligned}
\frac{n}{n^{*}}= & +\frac{2}{n(n-1)(n-2)} \\
& \times \sum_{i=1}^{n-1}(n-k)(n-k-1)(n-k-2) \rho_{k}
\end{aligned}
$$

$n^{*}$ stands for the effective number of observations to account for autocorrelation in the data, whereas $\rho_{k}$ is the serial correlation between ranks of the observations for lag- $k$ respectively. In the present study, modified MK test method has been employed for detection of trends in STIs.

\subsubsection{Sen's slope method}

Sen's slope method is used to compute magnitude of trend line. This is defined as the median of all 
combination of data pairs for the whole dataset. It is given as follows (Sen 1968):

$$
Q=\operatorname{Median}\left(\frac{x_{j}-x_{i}}{j-i}\right) \quad \text { for } i=1,2, \ldots, n
$$

where $x_{i}$ and $x_{j}$ are data values at time $i$ and $j$ respectively. $Q$ is an estimate of the trend magnitude. Positive value of $Q$ indicates an upward (increasing) trend and negative value of $Q$ indicates a downward (decreasing) trend in time series.

\subsubsection{Cumulative Sum (CUSUM) chart}

The CUSUM chart introduced by Page (1961) is a nonparametric test based technique and is used to study sequential changes in one or more variables. It is cumulative sum of the deviations of a time series about a target value (mean of time series) (Mansell 1997). The CUSUM is widely used because of its ability to detect unusual patterns, simplicity and better graphical representation of results (Sonali and Kumar 2013). Kattel and Yao (2013) have described procedures for constructing CUSUM charts. Let us consider $x$ samples, each of $n$ size with mean $\mu_{0}$ and standard deviation $\sigma$. Then, cumulative sum of deviation $\left(S_{i}\right)$ from target value (mean) is calculated such as:

$$
S_{i}=\sum_{j=1}^{i}\left(x_{j}-\mu_{0}\right)
$$

where $x_{j}$ is the mean of $j$ th sample. The Upper Control Limit (UCL) and Lower Control Limit (LUC) of the CUSUM chart is defined by a statistical parameter $H$ (decision interval) which should not exceed five times of sample standard deviation. The shift in mean is detected in CUSUM chart by reference or allowable value $(k)$. It is selected as halfway between target $\mu_{0}$ and shift of mean $\left(x_{j}-\mu_{0}\right)$. In this study, limits of UCL and LCL have been estimated between $\pm 2^{*} \sigma$ and $k=0.5$, respectively.

\subsection{Statistical downscaling model (SDSM)}

Statistical downscaling model (SDSM) is a combination of Multiple Regressions (MLR) and Stochastic Weather Generator (SWG) based downscaling methods (Wilby et al. 2002). SDSM has shown advantage over other statistical downscaling approaches such as weather generators and weather typing because of its better ability in describing interannual variability. It has widely been used throughout the world to downscale single-site scenarios of daily surface weather variables from predictors of GCMs for assessing hydrologic responses in climate change scenarios (Dibike and Coulibaly 2005; Gagnon et al. 2005; Aherne et al. 2008; Combalicer et al. 2010; Huang et al. 2011; Goyal et al. 2012). A couple of studies, one by Meenu et al. (2012) and another by Mahmood and Babel (2013) have been conducted using SDSM in Indian subcontinent. They have downscaled daily $T_{\mathrm{Max}}$, $T_{\text {Min }}$ and precipitation (PCP) from predictors of HadCM3 under A2 and B2 scenarios to access hydrological impacts of climate change in TungaBhadra river basin, India and in Jhelum basin, Pakistan respectively.

In SDSM, the generation of station scale weather parameters is linearly conditioned by observed large scale predictors of atmosphere $(j=$ $1,2, \ldots, n)$. In case of unconditional process like temperature, a direct linear relationship is established between the predictand $U_{i}$ and selected NCEP/NCAR predictors $X_{i j}$ on individual station such as:

$$
U_{i}=\gamma_{0}+\sum_{j=1}^{n} \gamma_{j} X_{i j}+\varepsilon_{1}
$$

where $U_{i}$ is temperature on day $i$ and $X_{i j}$ is selected NCEP/NCAR predictors on day $i . \gamma_{\mathrm{j}}$ are regression coefficients estimated for each month using leastsquares regression and $\varepsilon_{1}$ is a model error. It is generated stochastically using a series of serially independent Gaussian numbers and is added to the deterministic components on daily basis.

The relevant predictors are selected based on explained variance, correlation analysis, partial correlation analysis, and scatter plots. The physical sensitivity between selected predictors and predictands has also been taken into account for the station (Khan et al. 2006). Monthly percentages of explained variance demonstrate the capability of a given predictor to give details of local climate variability (Gagnon et al. 2005). In the present work, the model has been structured as monthly model for downscaling of $T_{\mathrm{Max}}$ and $T_{\mathrm{Min}}$. This derives 12 regression equations between predictors and observed $T_{\text {Max }}$ and $T_{\text {Min }}$ for each station, one for each month. After establishing the model, the daily data of NCEP/NCAR and GCMs is implied to generate current and future daily weather series (Wilby et al. 2002; Wilby and Dawson 2007).

\subsection{Spatial interpolation method}

Spline interpolation is used to interpolate smoothly varying surfaces of phenomenon like temperature. This method has been widely used to show spatial distribution of climate variables (Xiangsheng et al. 2013). In this study, this interpolation method has been used to show spatial patterns of changes in magnitude (trend) of different STI 
( $T_{\text {Mean }}, T_{\text {Max }}, T_{\text {Min }}$ and DTR) in Sutlej river basin during 1971-2005 and 2011-2099 periods. The station-based values of Sen's slope derived from annual trend analysis of temperature parameters have been interpolated using this method under ArcGIS 9.3 environment. Spline interpolation determines values using a mathematical function that in general, minimizes surface curvature.

\section{Results}

\subsection{Stationwise trends in annual and seasonal STI using modified MK test for 1971-2005}

The results showing annual trend analysis of STI ( $T_{\text {Mean }}, T_{\text {Max }}, T_{\text {Min }}$ and DTR) for 1971-2005 have been presented in table 2 . The increasing as well as decreasing trends in $T_{\text {Mean }}, T_{\text {Max }}$ and $T_{\text {Min }}$ have been observed at different stations. Statistically insignificant decreasing trend in annual $T_{\text {Mean }}$ has been found at Kasol and Sunni opposite to Rampur which shows increasing trend for the same period. An upward statistically significant trend (95\% confidence level) in $T_{\text {Max }}$ at the rate (Q) of $0.04^{\circ} \mathrm{C} /$ year has been observed at Rampur and downward trend in $T_{\mathrm{Min}}$ at Kasol $\left(0.02^{\circ} \mathrm{C}\right.$ /year $)$ and Sunni $\left(0.06^{\circ} \mathrm{C} /\right.$ year) respectively. The increasing trend in DTR has been noticed at all the three stations but results are statistically significant at Sunni $\left(0.05^{\circ} \mathrm{C} /\right.$ year $)$ and Rampur $\left(0.04^{\circ} \mathrm{C} /\right.$ year $)$ only.

Table 3 provides the summary of the seasonal trend analysis of STI ( $T_{\text {Mean }}, T_{\text {Max }}, T_{\text {Min }}$ and DTR) for 1971-2005. During winter season (December, January, February), downward trends have been reported in $T_{\text {Mean }}, T_{\text {Max }}$ and $T_{\text {Min }}$ at Kasol and Sunni opposite to Rampur, which shows upward trends during this period. The results are statistically significant at $\mathrm{Kasol}\left(0.04^{\circ} \mathrm{C} /\right.$ year $)$ and Sunni $\left(0.06^{\circ} \mathrm{C} /\right.$ year $)$ for $T_{\text {Min }}$ and Rampur for $T_{\text {Mean }}$ $\left(0.05^{\circ} \mathrm{C} /\right.$ year $)$ and $T_{\text {Max }}\left(0.05^{\circ} \mathrm{C} /\right.$ year $)$ respectively. In spring season (March, April, May), only for $T_{\text {Min }}$ statistically significant decreasing trend has been found at Sunni and rate of change is $0.05^{\circ} \mathrm{C} /$ year. Statistically insignificant increasing trends in $T_{\text {Mean }}$ and $T_{\text {Max }}$ have been observed at Kasol and Rampur respectively. No statistically significant trends in $T_{\text {Mean }}, T_{\text {Max }}$ and $T_{\text {Min }}$ have been noticed during summer season (June, July, August) except at Sunni, which shows upward trend in $T_{\text {Max }}$ at the rate of $0.04^{\circ} \mathrm{C} /$ year. In autumn season (September, October, November), at $95 \%$ confidence level, decreasing trends in $T_{\text {Mean }}, T_{\text {Max }}$ and $T_{\text {Min }}$ have been reported at Kasol $\left(0.05^{\circ} \mathrm{C} /\right.$ year, $0.04^{\circ} \mathrm{C}$ /year and $0.03^{\circ} \mathrm{C} /$ year $)$ and Sunni $\left(0.04^{\circ} \mathrm{C} /\right.$ year $)$ for $T_{\text {Min }}$ respectively. In case of DTR, generally all the stations have shown increasing trends throughout all the seasons.

Table 2. Annual trend analysis of STI for 1971-2005 performed at all stations.

\begin{tabular}{|c|c|c|c|c|c|c|c|c|}
\hline \multirow[b]{2}{*}{ Station } & \multicolumn{2}{|r|}{$T_{\text {Mean }}$} & \multicolumn{2}{|r|}{$T_{\operatorname{Max}}$} & \multicolumn{2}{|r|}{$T_{\mathrm{Min}}$} & \multicolumn{2}{|r|}{ DTR } \\
\hline & $Z_{s}$ & $Q\left({ }^{\circ} \mathrm{C} /\right.$ year $)$ & $Z_{s}$ & $Q\left({ }^{\circ} \mathrm{C} /\right.$ year $)$ & $Z_{s}$ & $Q\left({ }^{\circ} \mathrm{C} /\right.$ year $)$ & $Z_{s}$ & $Q\left({ }^{\circ} \mathrm{C} /\right.$ year $)$ \\
\hline Kasol & $(-)$ & -0.02 & $(-)$ & -0.01 & $(-)^{*}$ & -0.02 & $(+)$ & 0.01 \\
\hline Sunni & $(-)$ & -0.03 & $(+)$ & 0.01 & $(-)^{*}$ & -0.06 & $(+)^{*}$ & 0.05 \\
\hline Rampur & $(+)$ & 0.03 & $(+)^{*}$ & 0.04 & $(+)$ & 0.02 & $(+)^{*}$ & 0.04 \\
\hline
\end{tabular}

* indicates that values are statistically significant at $5 \%$ level of significance.

Table 3. Seasonal trend analysis of STI for 1971-2005 performed at all stations.

\begin{tabular}{|c|c|c|c|c|c|c|c|c|c|}
\hline \multirow[b]{2}{*}{ Station } & \multirow[b]{2}{*}{ Season } & \multicolumn{2}{|r|}{$T_{\text {Mean }}$} & \multicolumn{2}{|r|}{$T_{\text {Max }}$} & \multicolumn{2}{|r|}{$T_{\text {Min }}$} & \multicolumn{2}{|r|}{ DTR } \\
\hline & & $Z_{s}$ & $Q\left({ }^{\circ} \mathrm{C} /\right.$ year $)$ & $Z_{s}$ & $Q\left({ }^{\circ} \mathrm{C} /\right.$ year $)$ & $Z_{s}$ & $Q\left({ }^{\circ} \mathrm{C} /\right.$ year $)$ & $Z_{s}$ & $Q\left({ }^{\circ} \mathrm{C} /\right.$ year $)$ \\
\hline \multirow[t]{4}{*}{ Kasol } & Winter & $(-)$ & -0.03 & $(-)$ & -0.02 & $(-)^{*}$ & -0.04 & $(+)$ & 0.01 \\
\hline & Spring & $(+)$ & 0.01 & $(+)$ & 0.01 & $(-)$ & -0.01 & $(+)$ & 0.02 \\
\hline & Summer & $(-)$ & -0.01 & $(+)$ & 0.01 & $(-)$ & -0.01 & $(+)$ & 0.07 \\
\hline & Autumn & $(-)^{*}$ & -0.05 & $(-)^{*}$ & -0.04 & $(-)^{*}$ & -0.03 & $(-)$ & -0.01 \\
\hline \multirow[t]{4}{*}{ Sunni } & Winter & $(-)^{*}$ & -0.05 & $(-)$ & -0.01 & $(-)^{*}$ & -0.06 & $(+)^{*}$ & 0.04 \\
\hline & Spring & $(-)$ & -0.02 & $(+)$ & 0.01 & $(-)^{*}$ & -0.05 & $(+)$ & 0.03 \\
\hline & Summer & $(+)$ & 0.03 & $(+)^{*}$ & 0.04 & $(-)$ & -0.03 & $(+)^{*}$ & 0.05 \\
\hline & Autumn & $(-)$ & -0.02 & $(+)$ & 0.01 & $(-)^{*}$ & -0.04 & $(+)$ & 0.02 \\
\hline \multirow[t]{4}{*}{ Rampur } & Winter & $(+)^{*}$ & 0.05 & $(+)^{*}$ & 0.05 & $(+)$ & 0.01 & $(+)^{*}$ & 0.05 \\
\hline & Spring & $(+)$ & 0.01 & $(+)$ & 0.01 & $(+)$ & 0.01 & $(+)$ & 0.03 \\
\hline & Summer & $(+)$ & 0.02 & $(+)$ & 0.02 & $(+)$ & 0.02 & $(+)$ & 0.03 \\
\hline & Autumn & $(+)$ & 0.01 & $(+)$ & 0.01 & $(+)$ & 0.01 & $(+)$ & 0.01 \\
\hline
\end{tabular}

* indicates that values are statistically significant at $5 \%$ level of significance. 

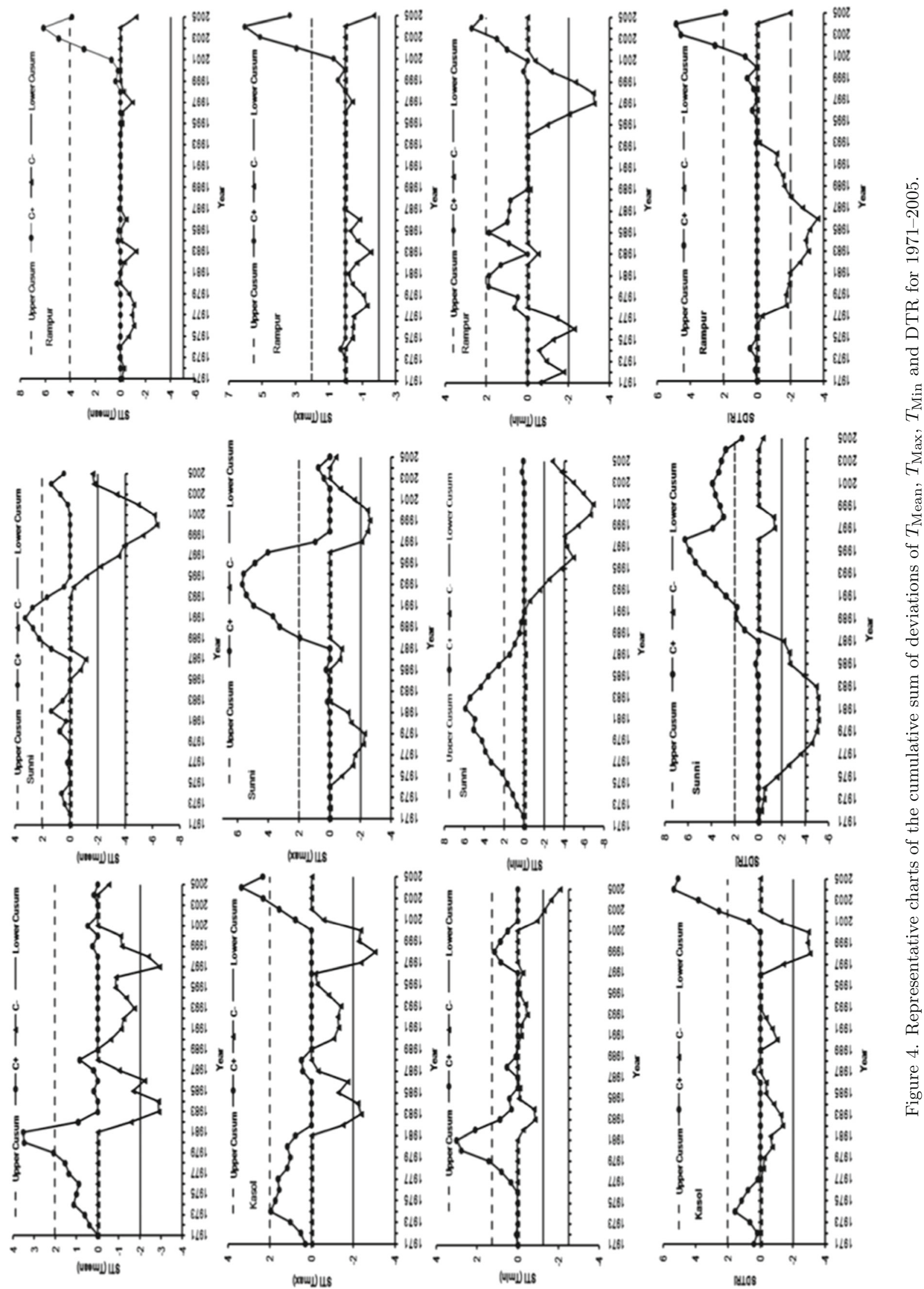

$\sum_{-1}^{\infty}$ 


\subsection{Thermal regime shift in annual STI using CUSUM charts for 1971-2005}

The sequential shift in observed time series (annual) of $T_{\text {Mean }}, T_{\text {Max }}, T_{\text {Min }}$ and DTR has been shown for all the stations in figure 4 with the help of CUSUM charts. According to Shapiro et al. (2010), regime shift is evaluated based on the change in the slope of CUSUM charts. The cumulative deviation from target mean should be zero if the variables are uniformly distributed for each year and random if it is above $\left(\mathrm{C}^{+}\right)$or below $\left(\mathrm{C}^{-}\right)$the target mean (Mansell 1997). A non-random pattern of temperature variability can be estimated from the chart if it is beyond $\pm 2 \sigma$ (Upper CUSUM and Lower CUSUM).

The interpretation of CUSUM charts has revealed a sharp positive regime shift beyond the limit of Upper CUSUM $(+2 \sigma)$ in $T_{\text {Max }}$ at Sunni from 1988 to 1997 followed by Rampur and Kasol from 2001 to 2005 respectively. A negative regime shift beyond the limit of Lower CUSUM $(-2 \sigma)$ has occurred on two occasions at Kasol (1982-1985 and 1997-2000) and Sunni (1978-1980 and 19972000), whereas no such negative regime shift has been noticed at Rampur. The positive shift $\left(\mathrm{C}^{+}\right)$ signifies a period when a value of $T_{\text {Max }}$ is above the climatic average and for negative shift $\left(\mathrm{C}^{-}\right)$, it is below the average. This explains why certain stations have shown increasing or decreasing annual trends in $T_{\mathrm{Max}}$ for the period of 19712005. The annual statistically insignificant downward trend in $T_{\text {Max }}$ at Kasol has been observed because of supremacy of cooling (1982-1985 and 1997-2005) instead of recent warming (2001-2005). In case of Sunni, the prolonged warming (19881997) with high rate has shown domination over cooling (1978-1980 and 1997-2000). Therefore, statistically insignificant increasing annual trend in $T_{\text {Max }}$ has been experienced at Sunni. Statistically significant trend in $T_{\mathrm{Max}}$ at Rampur is the result of recent warming (2001-2005).
Similarly for $T_{\mathrm{Min}}$, a positive regime shift has been observed at Kasol from 1979 to 1983 followed by the negative shift from 2003 to 2005 . The statistically significant decreasing trend in $T_{\mathrm{Min}}$ at Kasol may be because of continuous cooling prevailing after 2003 to 2005. At Sunni, the sharp negative shift after 1994 to 2005 has resulted in statistically significant downward trend in $T_{\text {Min }}$. However, continuous positive regime shift has been noticed at Rampur for $T_{\text {Min }}$ from 2003 to 2005 . In DTR, the negative shift at Kasol has occurred after 1997 and persisted till 2001 followed by positive shift, which persisted from 2002 to 2005. Sunni and Rampur have also shown positive regime shift in DTR, which occurs from 1990 to 2004 and 2001 to 2005. Due to these reasons, statistically significant increasing trend in DTR has been found at Sunni and Rampur, respectively.

\subsection{Decadal change in annual and seasonal STI for 1971-2005}

Decadal (annual and seasonwise) change in $T_{\text {Mean }}$, $T_{\text {Max }}, T_{\text {Min }}$ and DTR has been computed to determine whether the warming/cooling rate at a particular station during the period of 1971-2005 is uniform or not. Figure 5 shows nonuniform annual decadal change in $T_{\text {Mean }}, T_{\text {Max }}, T_{\text {Min }}$ and DTR for all the three stations in Sutlej river basin. At Kasol, warming in $T_{\text {Mean }}, T_{\text {Max }}$ and DTR has occurred in the decades of 1971-1980 and 2001-2005 followed by cooling in the decades of 1981-1990 and 19912000 respectively. Contrary to this, continuous cooling in $T_{\text {Min }}$ has been observed at Kasol starting from the decade of 1971-1980 to present (2001-2005). Other two stations show high variability in rate of change in $T_{\text {Mean }}, T_{\text {Max }}, T_{\text {Min }}$ and DTR with a common similarity; warming in the recent decade (2001-2005). Nonuniformity in rates of change at all the stations may be due to variation in physiographic characteristics of the areas they represent.

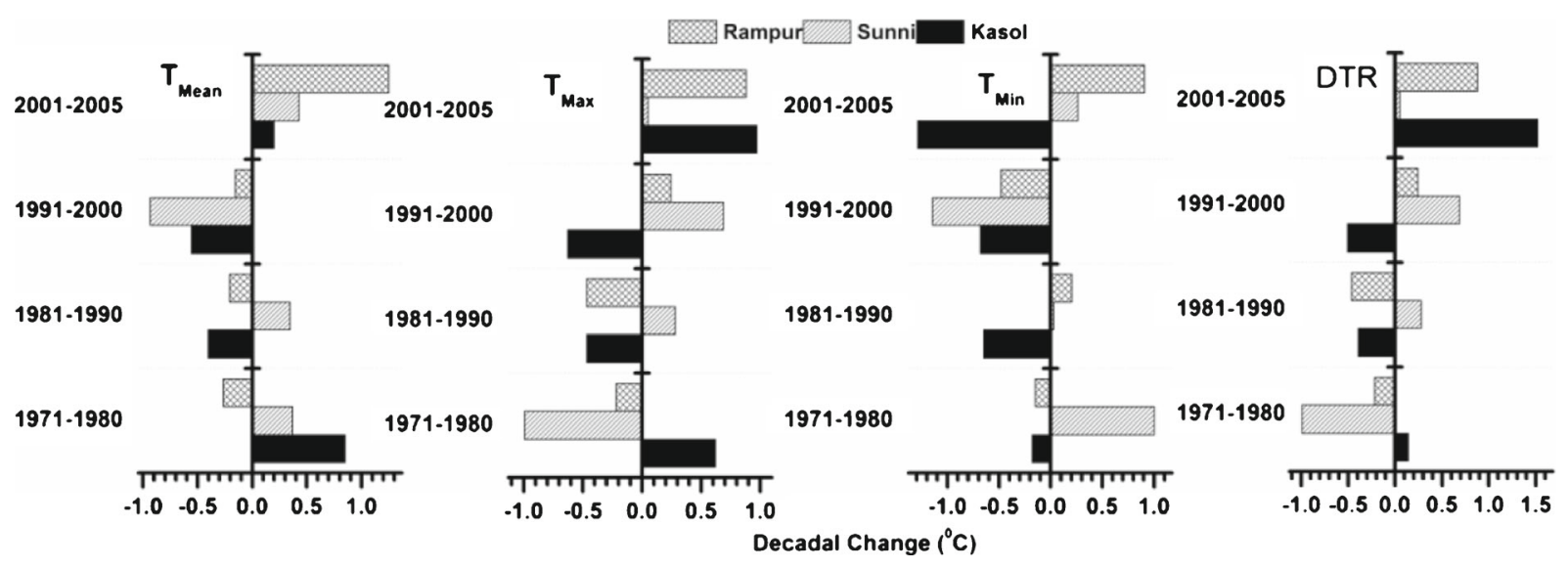

Figure 5. Decade to decade change in annual $T_{\text {Mean }}, T_{\text {Max }}, T_{\text {Min }}$ and DTR ( ${ }^{\circ} \mathrm{C} /$ year) in Sutlej river basin (1971-2005). 
Similarly, the results of inter-decadal (seasonwise) change in $T_{\text {Mean }}, T_{\text {Max }}, T_{\text {Min }}$ and DTR have been shown in figure 6. Generally, warming in $T_{\text {Mean }}, T_{\text {Max }}, T_{\text {Min }}$ and DTR have been observed at all the stations in the decade of 2001-2005 during winter and spring seasons. At Sunni, continuous warming with varying rates have been observed in $T_{\text {Max }}$ during winter, spring, summer, and autumn seasons from the decades of 1971-1980 to 20012005 , followed by continuous fall in $T_{\text {Min }}$ in the decade of 1991-2000, respectively.

\subsection{Generation of future time series for $T_{M a x}$ and $T_{M i n}$}

The generation of future time series for $T_{\mathrm{Max}}$ and $T_{\text {Min }}$ data at each station has been performed with the aid of SDSM. The screened sets of daily NCEP/NCAR predictors and predictands ( $T_{\mathrm{Max}}$ and $T_{\text {Min }}$ ) have been employed for model calibration using 21 years data (1970-1990). The model has been validated using the remaining 10 years' data (1991-2000) of NCEP/NCAR reanalysis

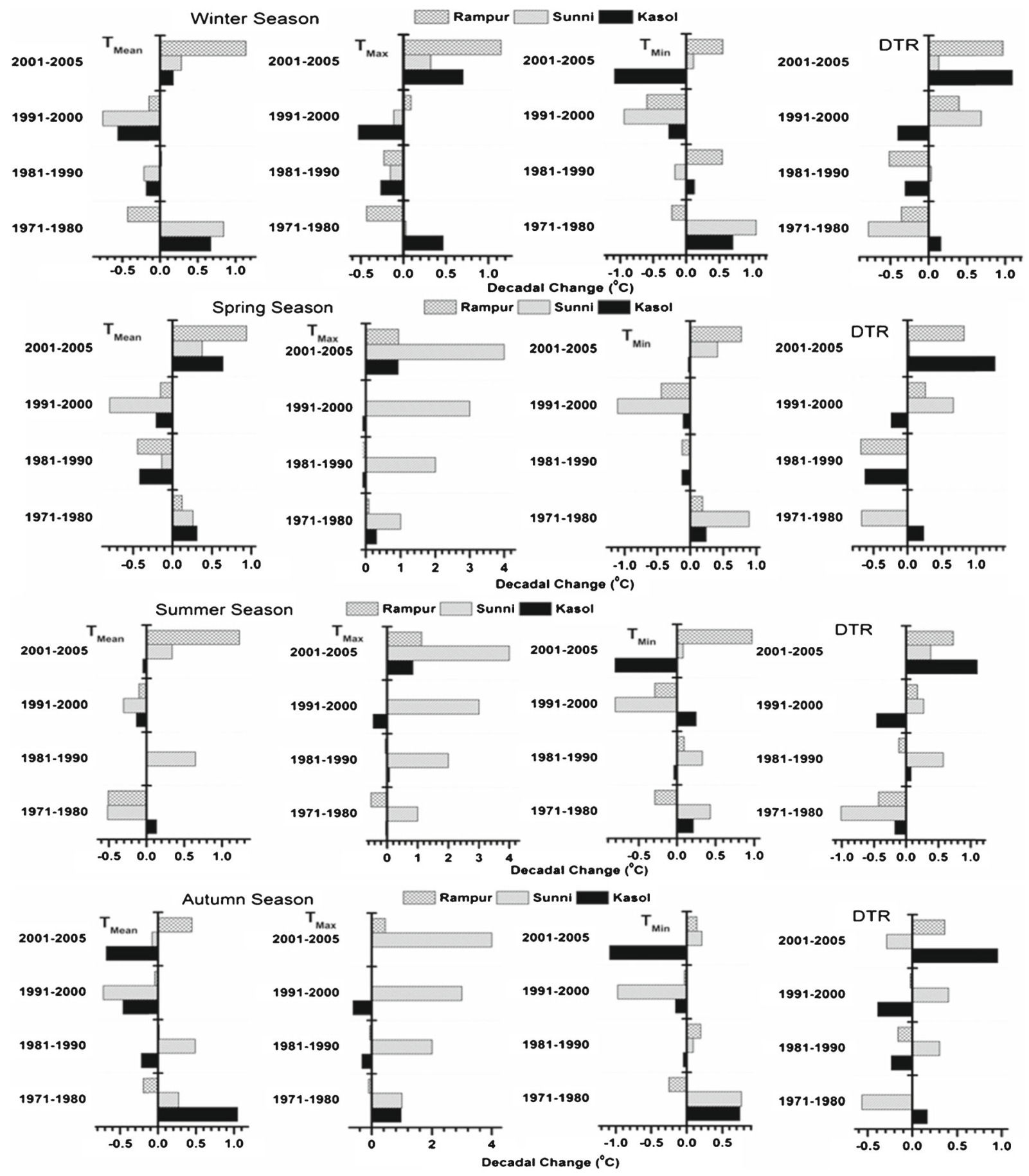

Figure 6. Decade to decade change in seasonal $T_{\mathrm{Mean}}, T_{\mathrm{Max}}, T_{\mathrm{Min}}$ and DTR $\left({ }^{\circ} \mathrm{C} /\right.$ year) in Sutlej river basin (1971-2005). 
datasets and simulation data, i.e., 20C3M scenario for CGCM3 and HadCM3 model respectively. During the calibration process, monthly submodel has been developed and downscaling process has been selected as unconditional process. A total of 20 ensembles are produced and mean of these ensembles have been used.

The statistical indicators such as the monthly average percentage of explained variance $(\% E)$ and the monthly average standard error (SE) have been used to describe downscaling results of daily $T_{\mathrm{Max}}$ and $T_{\mathrm{Min}}$ at each site in the basin. The monthly average value of $E$ (\%) for $T_{\text {Max }}$ ranges from $41.40 \%$ to $54.80 \%$ and $\mathrm{SE}\left({ }^{\circ} \mathrm{C}\right)$ from $1.99^{\circ}$ to $2.73^{\circ} \mathrm{C}$, whereas this lies in between $52.10 \%$ to $56.50 \%$ and $1.48^{\circ}$ to $1.74^{\circ} \mathrm{C}$ for $T_{\text {Min }}$ during calibration period for CGCM3 model. For HadCM3, the monthly average value of $E(\%)$ varies from $41.20 \%$ to $53.20 \%$ and $\mathrm{SE}\left({ }^{\circ} \mathrm{C}\right)$ from $2.03^{\circ}$ to $2.73^{\circ} \mathrm{C}$ for the
$T_{\text {Max }}$, while this is found between $53.70 \%$ to $62.60 \%$ and $1.50^{\circ}$ to $1.74^{\circ} \mathrm{C}$ for $T_{\text {Min }}$. The percentage of explained variance $(E \%)$ for several research studies has been found between $67 \%$ and $90 \%$ (Gagnon et al. 2005; Combalicer et al. 2010; Meenu et al. 2012). The results obtained in the present study are closer to such a level.

The graphs have been plotted against observed and downscaled mean monthly values of $T_{\text {Max }}$ and $T_{\mathrm{Min}}$ for calibration period. Figure 7 shows existence of a good agreement between observed and downscaled $T_{\text {Max }}$ and $T_{\text {Min }}$ for CGCM3 model. However, comparatively lower agreement has been recorded between observed and downscaled $T_{\mathrm{Max}}$ and $T_{\mathrm{Min}}$ for HadCM3 model (figure 8).

Similarly, the graphs have been plotted against observed and downscaled mean monthly values of $T_{\text {Max }}$ and $T_{\text {Min }}$ for validation period and it has been shown in figures 9 and 10. On the whole,
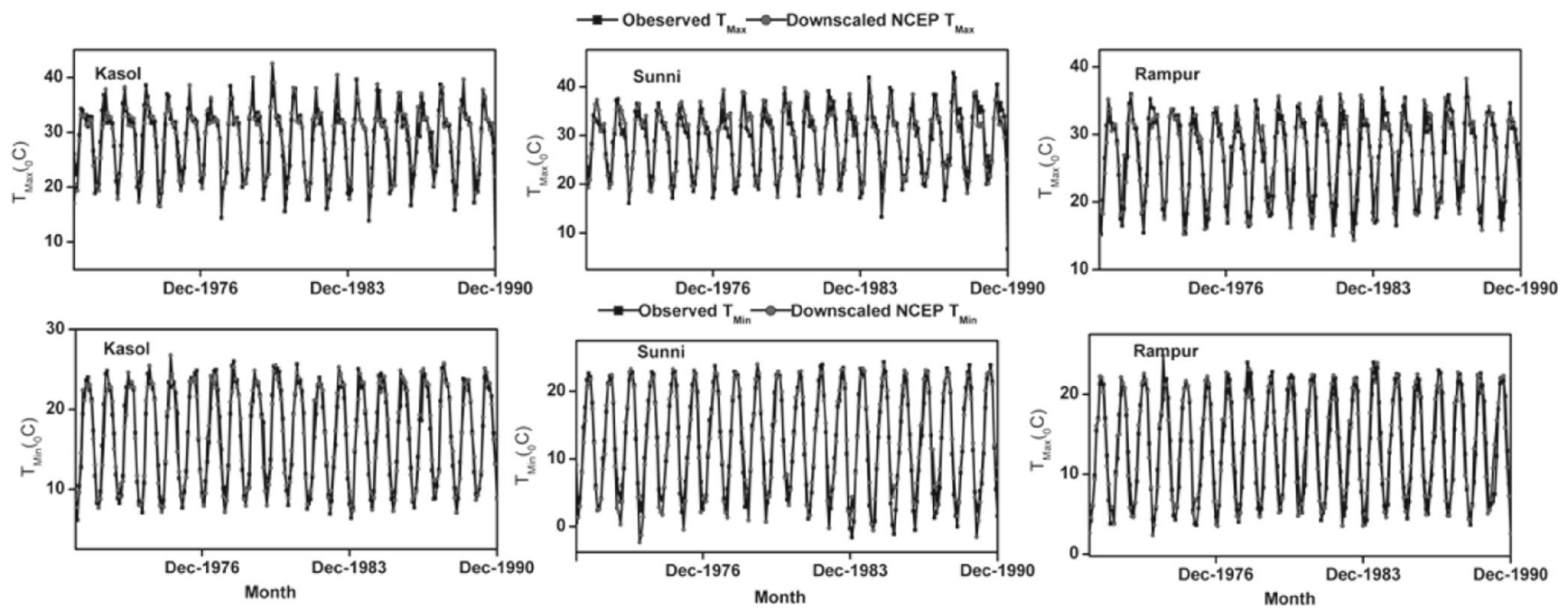

Figure 7. Comparing observed and simulated values of $T_{\mathrm{Max}}$ and $T_{\mathrm{Min}}$ during calibration period for CGCM3 model.
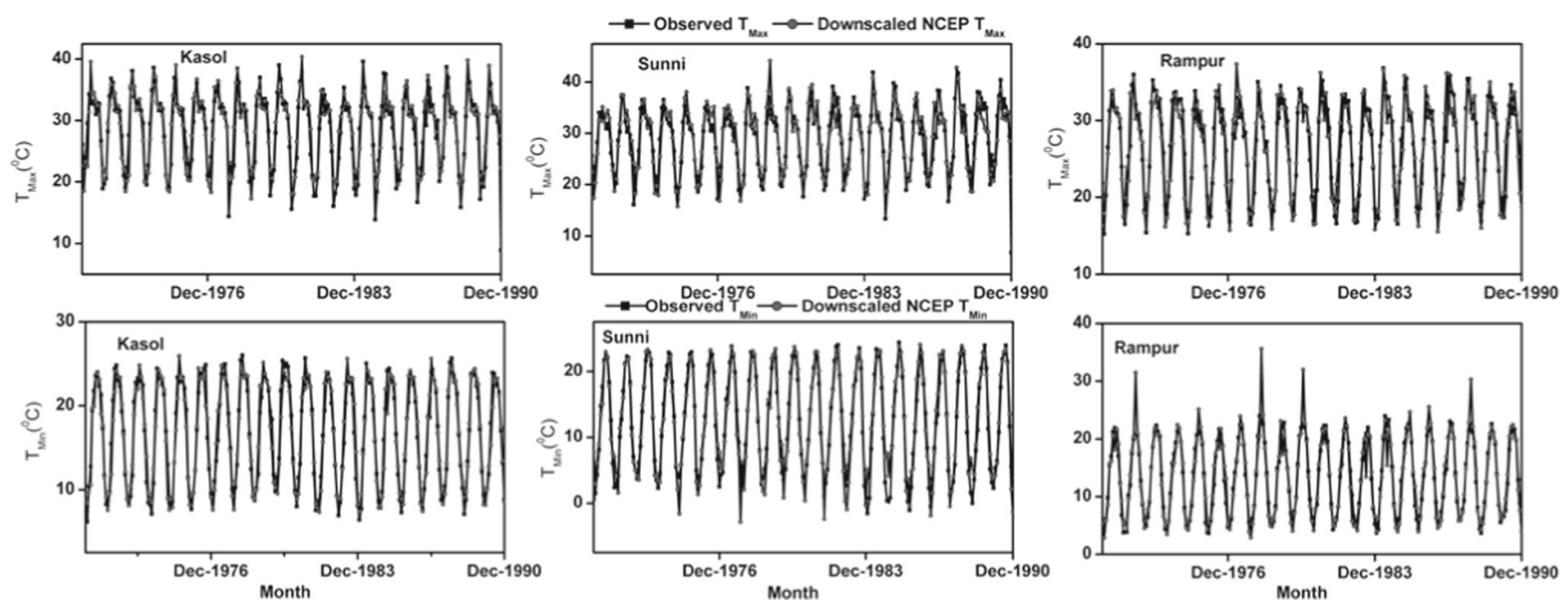

Figure 8. Comparing observed and simulated values of $T_{\mathrm{Max}}$ and $T_{\mathrm{Min}}$ during calibration period for HadCM3 model. 
downscaled $T_{\text {Max }}$ and $T_{\text {Min }}$ have showed a good agreement with the observed data. It can be observed from the figures that the simulated properties acceptably describe the observed statistics but deviation of value is noticed between them.

A comparison between SDSM downscaled $T_{\mathrm{Max}}$ and $T_{\mathrm{Min}}$ and observed series of $T_{\mathrm{Max}}$ and $T_{\mathrm{Min}}$ has been carried out in terms of the bias for validation period and details are provided in table 4 . The bias is the difference between the NCEP/NCAR downscaled value and the observed value of the statistic. In case of CGCM3 model, SDSM has yielded slightly higher estimates of mean $T_{\text {Max }}$ at Kasol $\left(1.48^{\circ} \mathrm{C}\right)$ and slightly lower at Rampur $\left(-0.23^{\circ} \mathrm{C}\right)$ compared with observed values. However, SDSM model has produced higher estimates of mean for $T_{\text {Min }}$ at Sunni $\left(2.20^{\circ} \mathrm{C}\right)$ and lower estimates at Rampur $\left(0.26^{\circ} \mathrm{C}\right)$ compared with those recorded
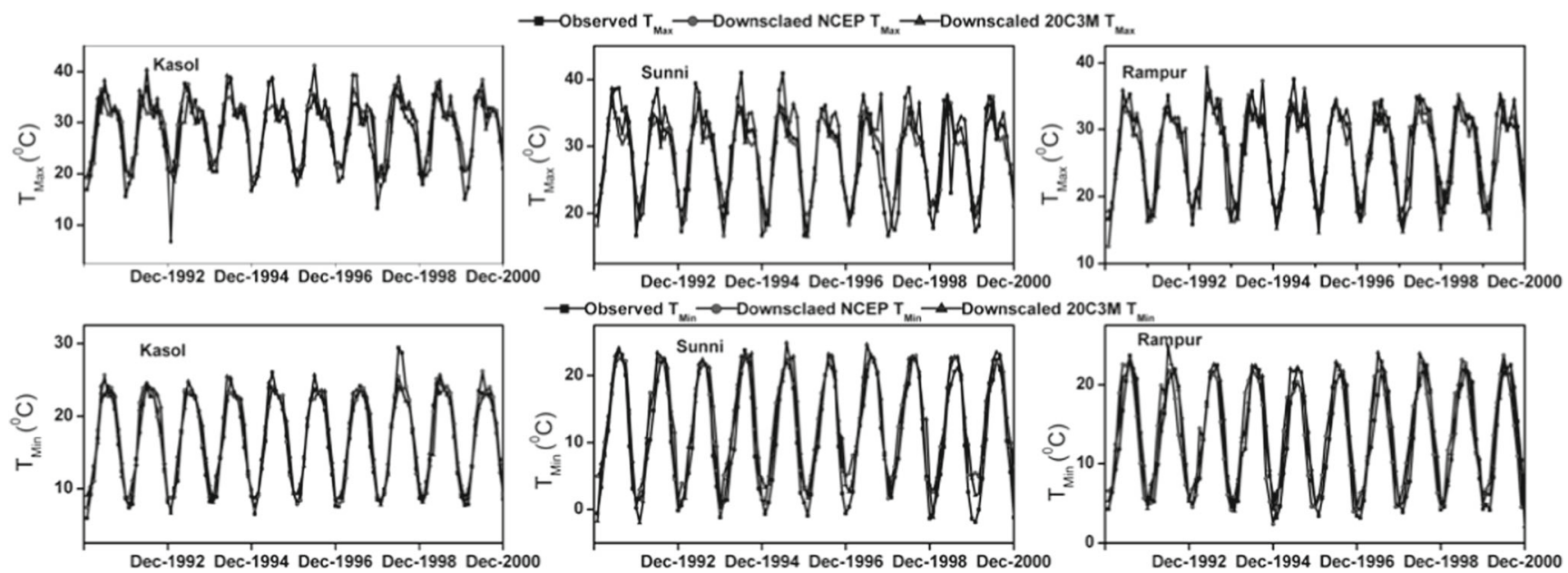

Dec-1992 Dec-1994 Dec-1996 Dec-1998 Dec-2000
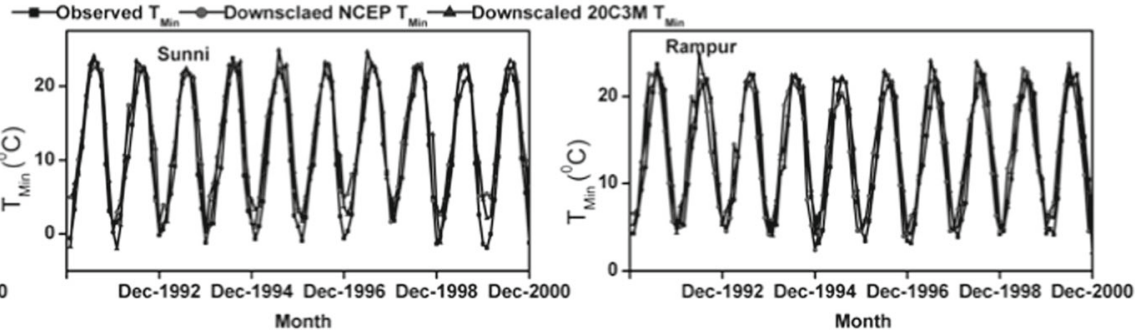

Figure 9. Comparing observed and simulated values of $T_{\mathrm{Max}}$ and $T_{\mathrm{Min}}$ during validation period for CGCM3 model.

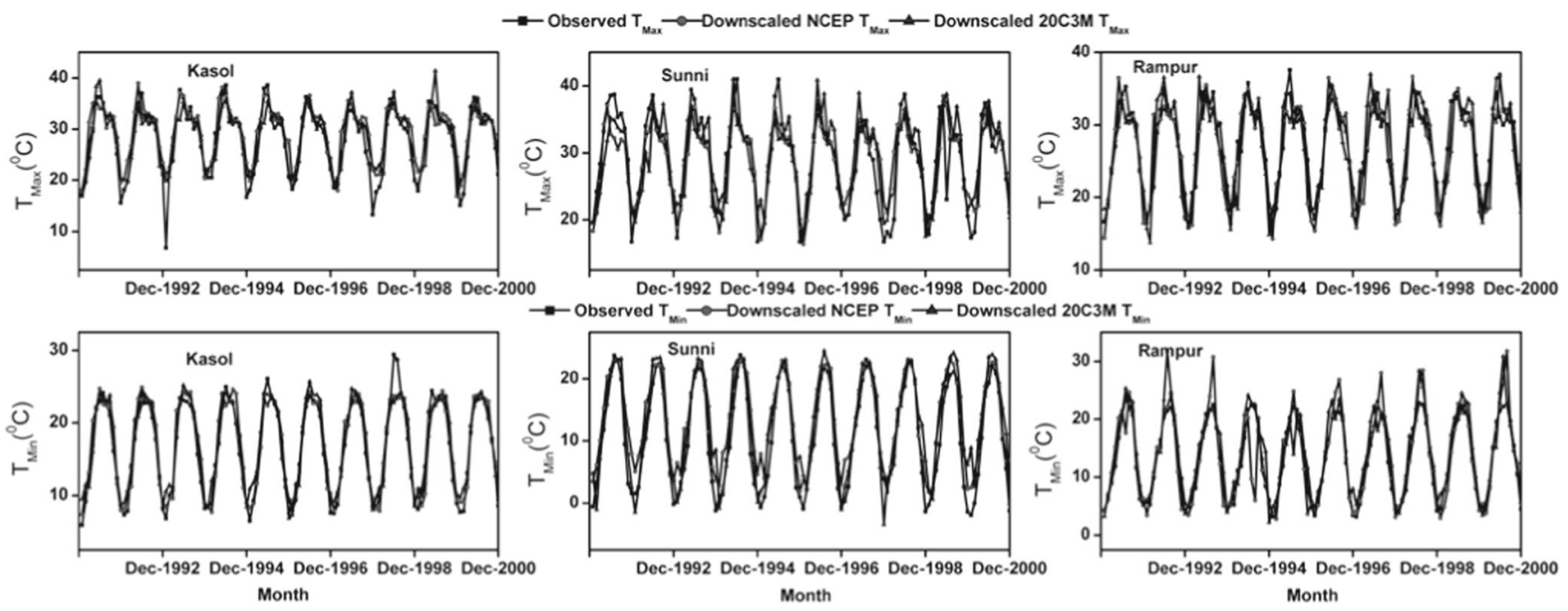

Figure 10. Comparing observed and simulated values of $T_{\mathrm{Max}}$ and $T_{\mathrm{Min}}$ during validation period for HadCM3 model.

Table 4. Bias between statistics of observed and downscaled NCEP/NCAR $T_{M a x}$ and $T_{M i n}$ during validation (1991-2000).

\begin{tabular}{|c|c|c|c|c|c|c|c|c|c|c|c|c|}
\hline \multirow[b]{3}{*}{ Station } & \multicolumn{6}{|c|}{ CGCM3 } & \multicolumn{6}{|c|}{ HadCM3 } \\
\hline & \multicolumn{3}{|c|}{$T_{\text {Max }}$ mean $\left({ }^{\circ} \mathrm{C}\right)$} & \multicolumn{3}{|c|}{$T_{\text {Min }}$ mean $\left({ }^{\circ} \mathrm{C}\right)$} & \multicolumn{3}{|c|}{$T_{\operatorname{Max}} \operatorname{mean}\left({ }^{\circ} \mathrm{C}\right)$} & \multicolumn{3}{|c|}{$T_{\text {Min }}$ mean $\left({ }^{\circ} \mathrm{C}\right)$} \\
\hline & $\overline{\mathrm{OBS}}$ & NCEP & Bias & OBS & NCEP & $\overline{\text { Bias }}$ & $\overline{\mathrm{OBS}}$ & NCEP & Bias & $\overline{\mathrm{OBS}}$ & NCEP & $\overline{\text { Bias }}$ \\
\hline Kasol & 27.99 & 29.47 & 1.48 & 16.69 & 17.15 & 0.46 & 27.99 & 29.47 & 1.48 & 16.69 & 17.04 & 0.35 \\
\hline Sunni & 28.88 & 28.49 & -0.39 & 11.07 & 13.27 & 2.20 & 28.88 & 29.11 & 0.23 & 11.07 & 13.54 & 2.47 \\
\hline Rampur & 27.2 & 26.97 & -0.23 & 13.38 & 13.64 & 0.26 & 27.2 & 26.79 & -0.41 & 13.38 & 13.53 & 0.15 \\
\hline
\end{tabular}


in study area. A similar pattern of bias has been noticed for HadCM3 model respectively.

Further, the performance of these two models in simulating temperature $\left(T_{\mathrm{Max}}\right.$ and $\left.T_{\mathrm{Min}}\right)$ under A2 scenario for 20 th century $(20 \mathrm{C} 3 \mathrm{M})$ have been compared with station based observed time series of temperature data for validation period (19912000). In case of CGCM3 model, the value of $R^{2}$ (correlation coefficient) and RMSE (Root Mean Square Error) has been found to be 0.80 and $2.67^{\circ} \mathrm{C}$ for $T_{\text {Max }}$ and 0.92 and $1.83^{\circ} \mathrm{C}$ for $T_{\text {Min }}$, respectively. Similarly for HadCM3 model, the value of $R^{2}$ and RMSE has been found to be 0.77 and $2.80^{\circ} \mathrm{C}$ for $T_{\mathrm{Max}}$ and 0.89 and $2.29^{\circ} \mathrm{C}$ for $T_{\mathrm{Min}}$ respectively. The higher value of $R^{2}$ has been obtained for $T_{\text {Max }}$ and $T_{\text {Min }}$ under 20C3M scenario of CGCM3 model as compared to HadCM3 model.

The calibrated model has further been used to generate future scenarios of $T_{\mathrm{Max}}$ and $T_{\mathrm{Min}}$ data using scenario Generator function. The future scenarios of daily $T_{\mathrm{Max}}$ and $T_{\mathrm{Min}}$ data have been generated from predictors of CGCM3 and HadCM3 model under A2 scenarios. These data have been generated on daily time steps for 89 years from 2011 to 2099. The remaining temperature parameters such as $T_{\text {Mean }}$ and DTR have been derived from projected $T_{\text {Max }}$ and $T_{\text {Min }}$ as discussed in section 3.1 for 2011-2099.

Table 5. Annual trend analysis of STI for 2011-2099 performed at all stations.

\begin{tabular}{|c|c|c|c|c|c|c|c|c|c|c|}
\hline \multirow[b]{2}{*}{ Station } & \multirow[b]{2}{*}{ Model } & \multirow[b]{2}{*}{ Scenario } & \multicolumn{2}{|r|}{$T_{\text {Mean }}$} & \multicolumn{2}{|r|}{$T_{\operatorname{Max}}$} & \multicolumn{2}{|r|}{$T_{\mathrm{Min}}$} & \multicolumn{2}{|r|}{ DTR } \\
\hline & & & $\bar{Z}$ & $Q\left({ }^{\circ} \mathrm{C} /\right.$ year $)$ & $\bar{Z}$ & $\overline{\left.Q\left({ }^{\circ} \mathrm{C} / \text { year }\right)\right)}$ & $\bar{Z}$ & $Q\left({ }^{\circ} \mathrm{C} /\right.$ year $)$ & $Z_{s}$ & $Q\left({ }^{\circ} \mathrm{C} /\right.$ year $)$ \\
\hline \multirow[t]{2}{*}{ Kasol } & CGCM3 & $\mathrm{A} 2$ & $(+)^{*}$ & 0.03 & $(+)^{*}$ & 0.02 & $(+)^{*}$ & 0.03 & $(-)$ & -0.00 \\
\hline & HadCM3 & $\mathrm{A} 2$ & $(+)^{*}$ & 0.01 & $(+)^{*}$ & 0.01 & $(+)^{*}$ & 0.01 & $(-)^{*}$ & -0.01 \\
\hline \multirow[t]{2}{*}{ Sunni } & CGCM3 & $\mathrm{A} 2$ & $(+)^{*}$ & 0.03 & $(+)^{*}$ & 0.01 & $(+)^{*}$ & 0.03 & $(-)^{*}$ & -0.02 \\
\hline & HadCM3 & $\mathrm{A} 2$ & $(+)^{*}$ & 0.06 & $(+)^{*}$ & 0.03 & $(+)^{*}$ & 0.04 & $(-)$ & -0.00 \\
\hline \multirow[t]{2}{*}{ Rampur } & CGCM3 & $\mathrm{A} 2$ & $(+)^{*}$ & 0.01 & $(+)$ & 0.01 & $(+)^{*}$ & 0.03 & $(-)^{*}$ & -0.01 \\
\hline & HadCM3 & $\mathrm{A} 2$ & $(+)^{*}$ & 0.04 & $(+)^{*}$ & 0.01 & $(+)^{*}$ & 0.10 & $(-)^{*}$ & -0.03 \\
\hline
\end{tabular}

* indicates that values are statistically significant at $5 \%$ level of significance.

Table 6. Seasonal trend analysis of STI for 2011-2099 performed at all stations.

\begin{tabular}{|c|c|c|c|c|c|c|c|c|c|c|}
\hline \multirow[b]{2}{*}{ Model } & \multirow[b]{2}{*}{ Scenario } & \multirow[b]{2}{*}{ Season } & \multicolumn{2}{|r|}{$T_{\text {Mean }}$} & \multicolumn{2}{|r|}{$T_{\operatorname{Max}}$} & \multicolumn{2}{|r|}{$T_{\mathrm{Min}}$} & \multicolumn{2}{|r|}{ DTR } \\
\hline & & & $Z_{s}$ & $Q\left({ }^{\circ} \mathrm{C} /\right.$ year $)$ & $Z_{s}$ & $Q\left({ }^{\circ} \mathrm{C} /\right.$ year $)$ & $Z_{s}$ & $Q\left({ }^{\circ} \mathrm{C} /\right.$ year $)$ & $Z_{s}$ & $Q\left({ }^{\circ} \mathrm{C} /\right.$ year $)$ \\
\hline Kasol & $\mathrm{A} 2$ & Winter & $(+)^{*}$ & 0.02 & $(+)^{*}$ & 0.02 & $(+)^{*}$ & 0.02 & $(+)$ & 0.01 \\
\hline \multirow[t]{3}{*}{ CGCM3 } & & Spring & $(+)^{*}$ & 0.02 & $(+)^{*}$ & 0.02 & $(+)^{*}$ & 0.02 & $(+)^{*}$ & 0.01 \\
\hline & & Summer & $(-)^{*}$ & -0.01 & $(-)^{*}$ & -0.03 & $(+)^{*}$ & 0.01 & $(-)^{*}$ & -0.02 \\
\hline & & Autumn & $(+)^{*}$ & 0.02 & $(+)^{*}$ & 0.01 & $(+)^{*}$ & 0.02 & $(-)$ & -0.00 \\
\hline \multirow[t]{4}{*}{ HadCM3 } & $\mathrm{A} 2$ & Winter & $(+)^{*}$ & 0.01 & $(+)^{*}$ & 0.01 & $(+)^{*}$ & 0.01 & $(+)^{*}$ & 0.01 \\
\hline & & Spring & $(+)$ & 0.00 & $(+)$ & 0.00 & $(+)^{*}$ & 0.01 & $(-)$ & -0.00 \\
\hline & & Summer & $(-)^{*}$ & -0.02 & $(-)^{*}$ & -0.03 & $(+)$ & 0.00 & $(-)^{*}$ & -0.02 \\
\hline & & Autumn & $(+)^{*}$ & 0.02 & $(+)$ & 0.00 & $(+)^{*}$ & 0.03 & $(-)^{*}$ & -0.01 \\
\hline Sunni & $\mathrm{A} 2$ & Winter & $(+)^{*}$ & 0.02 & $(+)^{*}$ & 0.01 & $(+)^{*}$ & 0.02 & $(-)^{*}$ & -0.01 \\
\hline \multirow[t]{3}{*}{ CGCM3 } & & Spring & $(+)^{*}$ & 0.03 & $(+)^{*}$ & 0.01 & $(+)^{*}$ & 0.03 & $(-)^{*}$ & -0.01 \\
\hline & & Summer & $(-)^{*}$ & -0.01 & $(-)^{*}$ & -0.02 & $(+)^{*}$ & 0.03 & $(-)^{*}$ & -0.04 \\
\hline & & Autumn & $(+)^{*}$ & 0.03 & $(+)^{*}$ & 0.01 & $(+)^{*}$ & 0.04 & $(-)^{*}$ & -0.01 \\
\hline \multirow[t]{4}{*}{ HadCM3 } & $\mathrm{A} 2$ & Winter & $(+)^{*}$ & 0.05 & $(+)^{*}$ & 0.03 & $(+)^{*}$ & 0.01 & $(+)^{*}$ & 0.01 \\
\hline & & Spring & $(+)^{*}$ & 0.05 & $(+)^{*}$ & 0.04 & $(+)^{*}$ & 0.04 & $(+)^{*}$ & 0.01 \\
\hline & & Summer & $(+)^{*}$ & 0.02 & $(+)^{*}$ & 0.01 & $(+)^{*}$ & 0.05 & $(-)^{*}$ & -0.01 \\
\hline & & Autumn & $(+)^{*}$ & 0.05 & $(+)^{*}$ & 0.01 & $(+)^{*}$ & 0.05 & $(-)^{*}$ & -0.01 \\
\hline Rampur & $\mathrm{A} 2$ & Winter & $(+)$ & 0.00 & $(-)$ & -0.00 & $(+)^{*}$ & 0.01 & $(-)$ & -0.01 \\
\hline \multirow[t]{3}{*}{ CGCM3 } & & Spring & $(+)^{*}$ & 0.01 & $(+)^{*}$ & 0.01 & $(+)^{*}$ & 0.02 & $(-)$ & -0.00 \\
\hline & & Summer & $(+)$ & 0.00 & $(-)^{*}$ & -0.01 & $(+)^{*}$ & 0.02 & $(-)^{*}$ & -0.02 \\
\hline & & Autumn & $(+)^{*}$ & 0.02 & $(+)^{*}$ & 0.01 & $(+)^{*}$ & 0.04 & $(-)^{*}$ & -0.01 \\
\hline \multirow[t]{4}{*}{ HadCM3 } & $\mathrm{A} 2$ & Winter & $(+)^{*}$ & 0.03 & $(+)^{*}$ & 0.01 & $(+)^{*}$ & 0.04 & $(-)$ & -0.00 \\
\hline & & Spring & $(+)^{*}$ & 0.02 & $(+)^{*}$ & 0.01 & $(+)^{*}$ & 0.05 & $(-)^{*}$ & -0.02 \\
\hline & & Summer & $(+)^{*}$ & 0.03 & $(-)$ & -0.00 & $(+)^{*}$ & 0.10 & $(-)^{*}$ & -0.05 \\
\hline & & Autumn & $(+)^{*}$ & 0.04 & $(+)^{*}$ & 0.01 & $(+)^{*}$ & 0.07 & $(-)^{*}$ & -0.01 \\
\hline
\end{tabular}

* indicates that values are statistically significant at $5 \%$ level of significance. 


\subsection{Stationwise trends in annual and seasonal STI} using modified MK test for 2011-2099

The modified MK test has been applied on future time series (2011-2099) of temperature data which has been generated under A2 forcing of CGCM3 and HadCM3 models as discussed in section 5.1 respectively. Similar method as discussed in section 3.2 has been adopted for deriving STI for future temperature data $\left(T_{\text {Mean }}, T_{\text {Max }}, T_{\text {Min }}\right.$ and DTR). The results of modified MK test showing annual trends in $T_{\text {Mean }}, T_{\text {Max, }}, T_{\text {Min }}$ and DTR have been given in table 5 . The study reveals statistically significant increasing trends in $T_{\text {Mean }}$, $T_{\text {Max }}$ and $T_{\text {Min }}$ at all the three stations under A2 scenario of both the models at different rates. Except at Kasol, the highest rate of increase in $T_{\text {Mean }}, T_{\text {Max }}$ and $T_{\text {Min }}$ has been reported under HadCM3 model for the period of 2011-2099. The magnitude of increase under A2 scenario for CGCM3 model in $T_{\text {Mean }}, T_{\text {Max }}$ and $T_{\text {Min }}$ are $0.03^{\circ} \mathrm{C} /$ year, $0.02^{\circ} \mathrm{C} /$ year, $0.03^{\circ} \mathrm{C} /$ year at Kasol, $0.03^{\circ} \mathrm{C} /$ year, $0.01^{\circ} \mathrm{C} /$ year, $0.03^{\circ} \mathrm{C} /$ year at Sunni and $0.01^{\circ} \mathrm{C} /$ year, $0.01^{\circ} \mathrm{C} /$ year, $0.03^{\circ} \mathrm{C} /$ year at Rampur respectively. Similarly for HadCM3 model, the rate of increase are $0.01^{\circ} \mathrm{C} /$ year, $0.01^{\circ} \mathrm{C} /$ year, $0.01^{\circ} \mathrm{C} /$ year at Kasol, $0.06^{\circ} \mathrm{C} /$ year, $0.03^{\circ} \mathrm{C} /$ year, $0.04^{\circ} \mathrm{C} /$ year at Sunni, and $0.04^{\circ} \mathrm{C} /$ year, $0.01^{\circ} \mathrm{C} /$ year, $0.10^{\circ} \mathrm{C} /$ year at Rampur respectively. The rate of increase is higher for $T_{\text {Min }}$ compared to $T_{\text {Max }}$. The annual downward trends in DTR have been reported at all the three stations under both the models at different rates.

Table 6 provides the summary of the seasonal trend analysis of projected STI $\left(T_{\text {Mean }}, T_{\text {Max }}, T_{\text {Min }}\right.$ and DTR) under A2 scenario of CGCM3 and HadCM3 models for 2011-2099. Both the models have revealed similar patterns of trends in $T_{\text {Mean }}$, $T_{\mathrm{Max}}$ and $T_{\mathrm{Min}}$ at all the three stations for all the four seasons except at Sunni which shows obvious differences in trends during summer season. Statistically significant upward trends in $T_{\text {Mean }}, T_{\text {Max }}$ and $T_{\mathrm{Min}}$ have been found during winter, spring, and autumn seasons for both the models at all the three stations. During summer season (CGCM3 model), statistically significant decreasing trends in $T_{\text {Max }}$ have been observed at Kasol, Sunni, and Rampur stations followed by $T_{\text {Mean }}$ at Kasol and
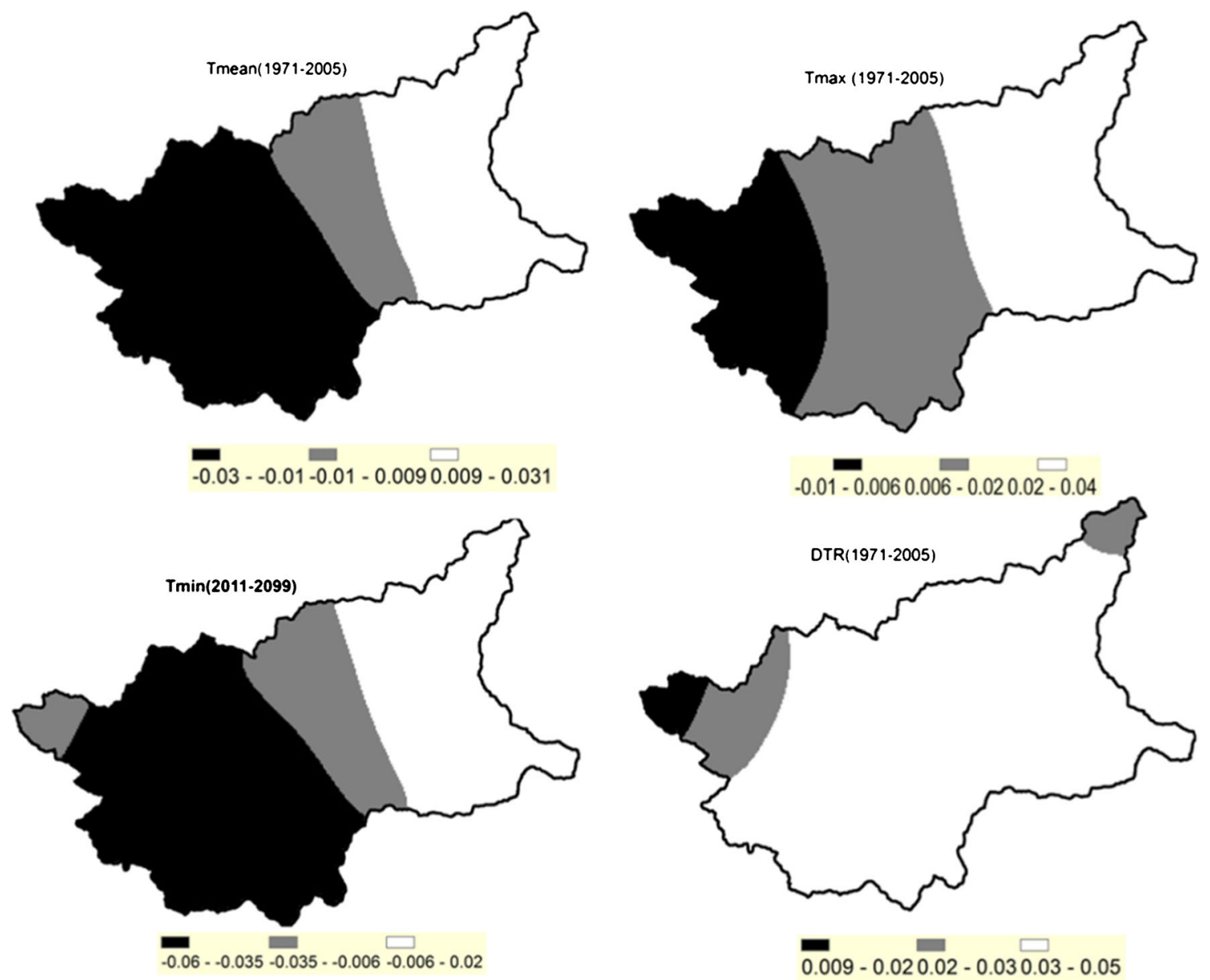

Figure 11. Spatial distribution of annual $T_{\text {Mean }}, T_{\mathrm{Max}}, T_{\mathrm{Min}}$ and DTR for 1971-2005. 
Sunni, respectively. In contrast, statistically significant increasing trends in $T_{\text {Mean }}$ and $T_{\text {Max }}$ have been noticed at Sunni during summer season under A2 scenario of HadCM3 model. The seasonal trend analysis of DTR has revealed decreasing trends at Rampur and increasing as well as decreasing trends at Kasol and Sunni, respectively.

\subsection{Spatial patterns of change in STI during 1971-2005 and 2011-2099}

The spatial patterns of temporal trends in STI $\left(T_{\text {Mean }}, T_{\text {Max }}, T_{\text {Min }}\right.$ and DTR $)$ in terms of magnitude for the period 1971-2005 have been shown in figure 11. Approximately half area of the basin extending from centre to south-west shows decrease $\left(0.03^{\circ} \mathrm{C}\right.$ to $0.01^{\circ} \mathrm{C}$ /year $)$ in $T_{\text {Mean }}$ followed by increase in remaining parts of the basin with highest increase $\left(0.009^{\circ} \mathrm{C}\right.$ to $0.03^{\circ} \mathrm{C} /$ year $)$ in the eastern region. The highest rise $\left(0.02^{\circ} \mathrm{C}\right.$ to $0.04^{\circ} \mathrm{C} /$ year) in $T_{\text {Max }}$ has been observed in the eastern part of the basin followed by a modest increase $\left(0.006^{\circ} \mathrm{C}\right.$ to $0.02^{\circ} \mathrm{C} /$ year $)$ in the central region, and fall in the western region of the basin. Most parts of the basin, except the eastern part have revealed decline in $T_{\text {Min }}$ and it is maximum in the south and southwestern parts of the basin. The entire basin has witnessed increase in DTR with varying rates.

Similarly, the temporal trends in $T_{\text {Mean }}$, $T_{\text {Max }}, T_{\text {Min }}$ and DTR for the future period $(2011-$ 2099) under A2 scenario of CGCM3 and HadCM3 models have been shown in figures 12 and 13, respectively. Both the models show obvious differences in patterns and rate of change with a common similarity; increase in $T_{\text {Mean }}, T_{\text {Max }}$ and $T_{\text {Min }}$ and decrease in DTR throughout the basin. The lowest rise under CGCM3 model in $T_{\text {Mean }}$ has been observed in the eastern region and the highest in central and western regions of the basin. Contrary to this, under HadCM3 model the modest rise in $T_{\text {Mean }}$ has been observed in the eastern region followed by the highest rise in central and southcentral regions of the basin.
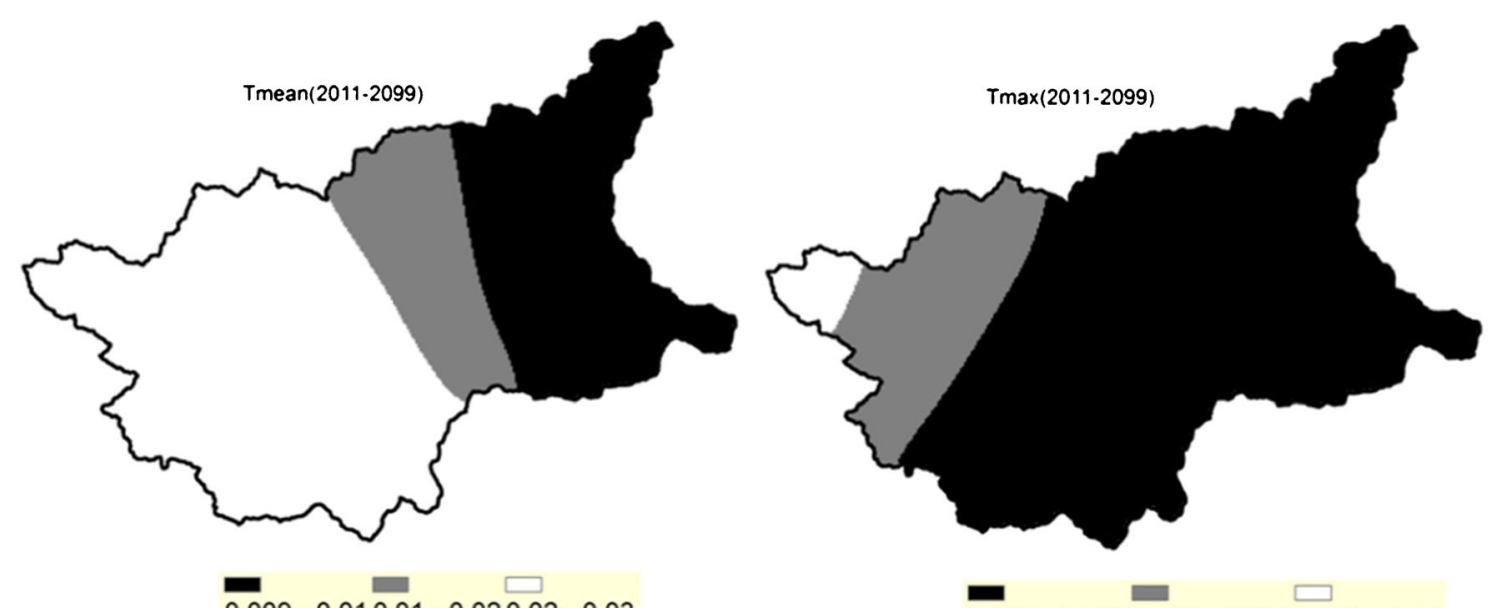

$0.009-0.010 .01-0.020 .02-0.03$
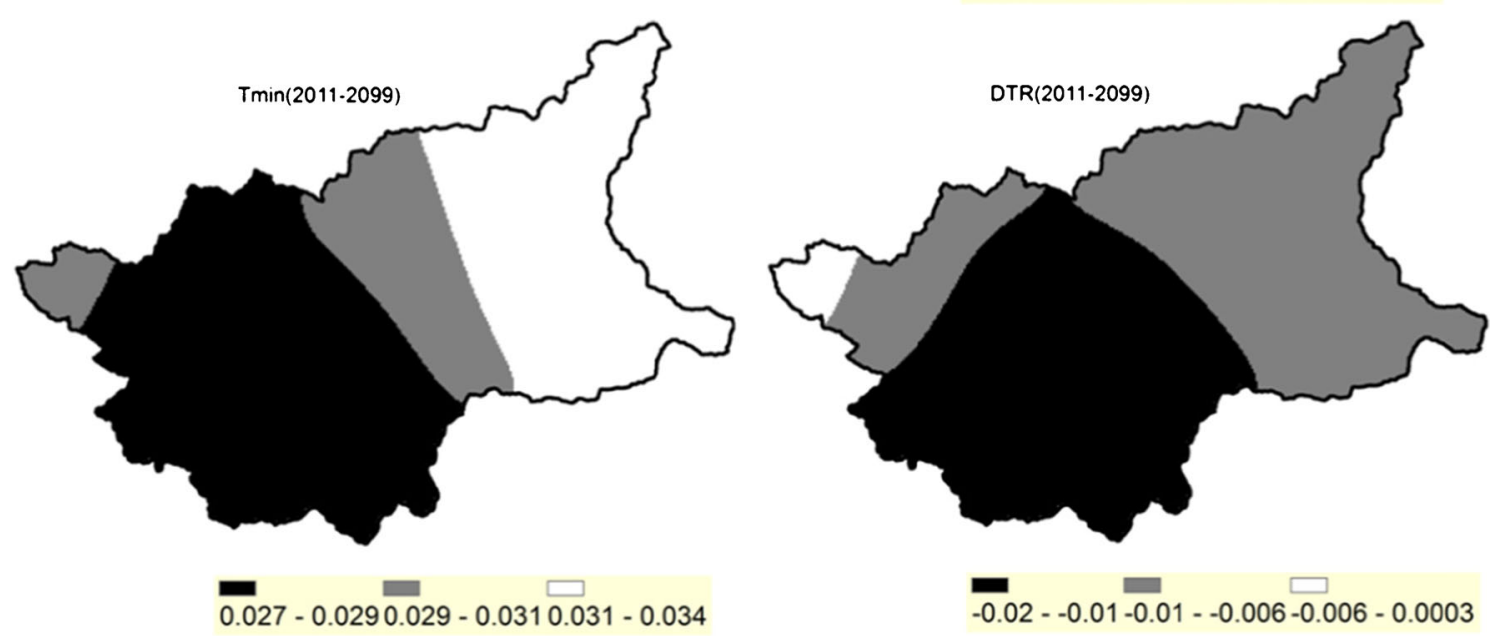

Figure 12. Spatial distribution of annual $T_{\text {Mean }}, T_{\mathrm{Max}}, T_{\mathrm{Min}}$ and DTR for 2011-2099 under A2 scenario of CGCM3. 

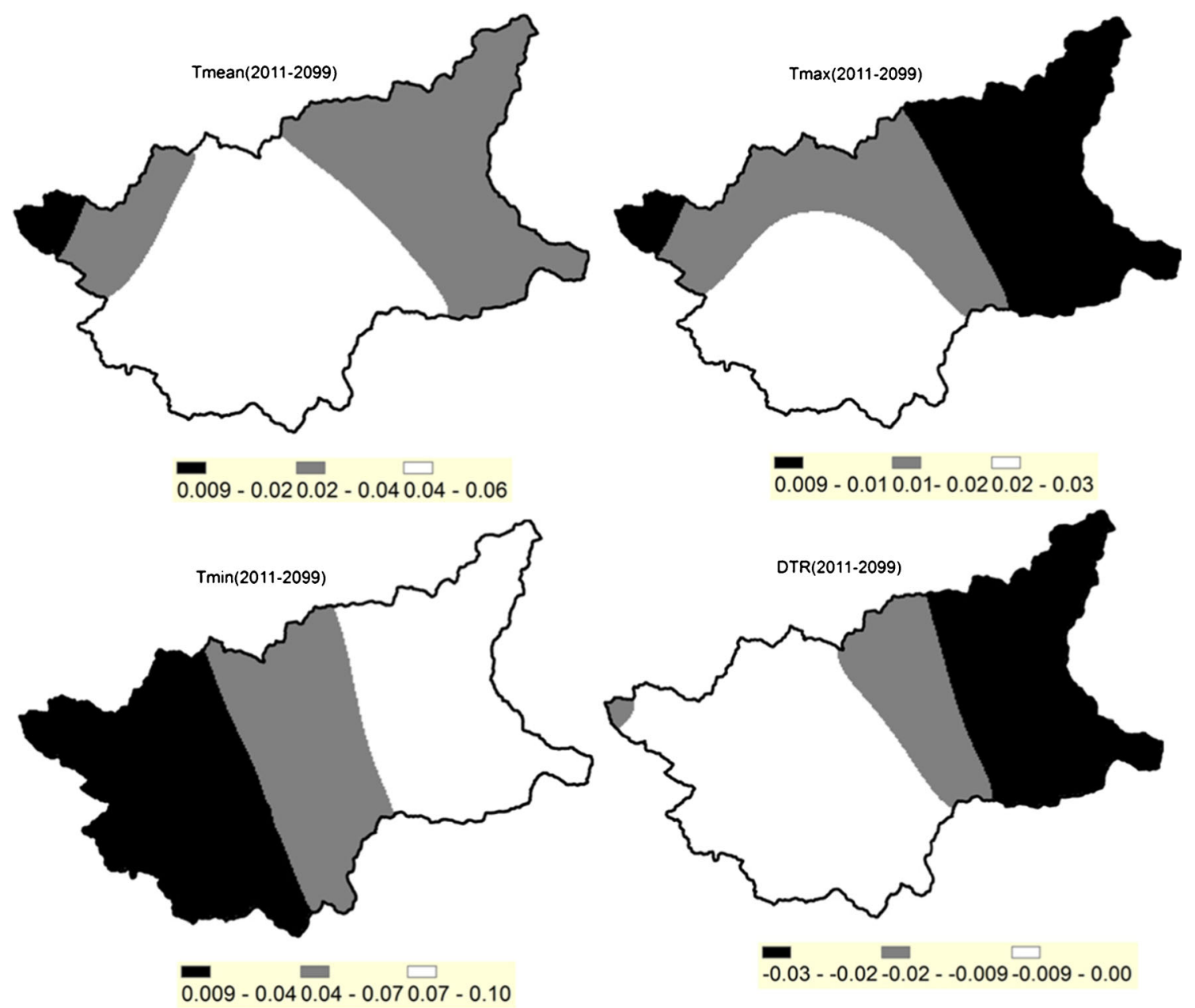

Figure 13. Spatial distribution of annual $T_{\text {Mean }}, T_{\mathrm{Max}}, T_{\mathrm{Min}}$ and DTR for 2011-2099 under A2 scenario of HadCM3.

\section{Discussions and conclusions}

In the present study, a comprehensive trend analysis (annual and seasonwise) of $T_{\text {Mean }}, T_{\text {Max }}, T_{\text {Min }}$ and DTR has been performed using 35 years (19712005) observed data. The analysis of decadal change and interpretation of CUSUM charts has shown enhanced warming during the period 20012005. A sharp positive regime shift in annual $T_{\text {Max }}$ has been observed at Kasol from 2001 to 2005, Sunni from 1988 to 1997, Rampur from 2001 to 2005, and in DTR at Kasol from 2002 to 2005, Sunni from 1990 to 2004, Rampur from 2001 to 2005 , respectively. To see the change in patterns of future data, plausible scenario of temperature data for future periods (2011-2099) has been generated using SDSM from large scale predictors of CGCM3 and HadCM3 models under A2 scenario.

The results of annual trend analysis have revealed statistically insignificant (at 95\% confidence level) decreasing trends in $T_{\text {Mean }}$ at Kasol and Sunni followed by increasing trend at Rampur during 1971-2005. As per the analysis of future scenarios, there is strong probability that all the stations would exhibit statistically significant increasing trends in $T_{\text {Mean }}$. The increase in $T_{\text {Max }}$ at Sunni and Rampur is expected to be continued in future while at Kasol, earlier it was decreasing trend but for future data it is increasing trend. During 1971-2005, statistically significant decreasing trends in $T_{\text {Min }}$ have been observed at Kasol and Sunni and increasing trend at Rampur (statistically insignificant). While using future scenarios, there is likelihood of rise in annual $T_{\text {Min }}$ at all the stations as trends (increasing) are statistically significant. In case of DTR, there was rise during 1971-2005, while there is a fall using future scenarios. This may be attributed to the fact that predicted increase in $T_{\mathrm{Min}}$ is more than the corresponding increase in $T_{\text {Max }}$ during the same period.

Similarly, seasonal trend analysis of projected data has revealed that rise in $T_{\text {Mean }}, T_{\text {Max }}$ and $T_{\text {Min }}$ would occur during winter, spring, and autumn seasons for both the models at all the three stations. During summer season for CGCM3 model, decrease in $T_{\text {Max }}$ would exhibit at Kasol, Sunni, and Rampur stations followed by $T_{\text {Mean }}$ at Kasol 
and Sunni, respectively. In contrast, there is probability of rise in $T_{\text {Mean }}$ and $T_{\text {Max }}$ at Sunni during summer season under A2 scenario of HadCM3 model. The results obtained from CGCM3 model are expected to be more reliable than HadCM3 because of higher $R^{2}$ for CGCM3 model during validation period. These warming patterns may have significant impacts on water resources and hydropower generation in the Sutlej river basin, India.

\section{References}

Aherne J, Futter M N and Dillion P J 2008 The impacts of future climate change and sulphur emission reductions on acidification recovery at Plastic Lake, Ontario; Hydrol. Earth Syst. Sci. 12(2) 383-392.

Anandhi A, Shrinivas V V, Nanjundiah R S and Kumar D N 2009 Role of predictors in downscaling surface temperature to river basin in India for IPCC SRES scenarios using support vector machine; Int. J. Climatol. 29(4) 583-603.

Anandhi A, Shrinivas V V, Nanjundiah R S and Kumar D N 2008 Downscaling precipitation to river basin in India for IPCC SRES scenarios using support vector machine; Int. J. Climatol. 28(3) 401-420, doi: 10.1002/joc.1529.

Bhutiyani M R, Kale V S and Pawar N J 2007 Long term trends in maximum, minimum and mean annual temperatures across the northwestern Himalaya during the twentieth century; Climate Change 85 159-177.

Bhutiyani M R, Kale V S and Pawar N J 2009 Climate change and the precipitation variations in the northwestern Himalaya: 1866-2006; Int. J. Climatol., doi: 10.1002/joc. 1920 .

Borgaonkar H P, Pant G B and Rupa Kumar K 1996 Ring-width variations in Cedras deodara and its climatic response over the western Himalaya; Int. J. Climatol. 16 1409-1422.

Canadian Climate Impacts Scenarios (CCIS) available at http://www.cics.uvic.ca/scenarios/index.cgi.

Combalicer E A, Cruz R V O, Lee S and Im S 2010 Assessing climate change impacts on water balance in the Mount Makiling forest, Philippines; J. Earth Syst. Sci 119(3) 265-283.

Cunderlik J M and Burn D H 2002 Local and regional trends in monthly maximum flows in southern British Columbia; Can. Water Resour. J. 27(2) 191-212.

Cunderlik J M and Burn D H 2004 Linkages between regional trends in monthly maximum flows and selected climatic variables; ASCE J. Hydrol. Eng. 9(4) 246-256.

Data access integration portal available at http://loki.qc.ec. gc.ca/DAI/predictors-e.html.

Dibike Y B and Coulibaly P 2005 Hydrologic impact of climate change in the Saguenay watershed: Comparison of downscaling methods and hydrologic models; J. Hydrol. 307 145-163.

Fowler H J, Blenkinsop S and Tebaldi C 2007 Linking climate change modelling to impacts studies: Recent advances in downscaling techniques for hydrological modelling; Int. J. Climatol. 27(12) 1547-1578.

Gagnon S, Singh B, Roussselle J and Roy L 2005 An application of the statistical downscaling model (SDSM) to simulate climatic data for stream flow modelling in Québec; Can. Water. Resour. J. 30(4) 297-314.

Ghosh S 2010 SVM-PGSL coupled approach for statistical downscaling to predict rainfall from GCM output; $J$. Geophys. Res. 115 D22102, doi: 10.1029/2009JD013548.
Goyal M K, Burn D H and Ojha C S P 2012 Statistical downscaling of temperatures under climate change scenarios for Thames river basin, Canada; Int. J. Global Warming 4(1) 13-30.

Grubbs F E 1969 Procedures for detecting outlying observations in samples; Technometrics 11(1) 13-14.

Hamed K H and Rao A R 1998 A modified Mann-Kendall test for autocorrelated data; J. Hydrol. 204 182-196.

Helsel D R and Hirsch R M 1992 Statistical Methods in Water Resources; Elsevier, Amsterdam, 522p, http:// pubs.usgs.gov/twri/twri4a3/html/pdf_new.html.

Hess A, Iyer H and Malm W 2001 Linear trend analysis: A comparison of methods; Atmos. Environ. 35 5211-5222.

Hewitson B C and Crane R G 1996 Climate downscaling: Techniques and application; Climate Change 7 85-95.

Huang J, Zhang J, Zhang Z, Xu C Y, Wang B and Yao J 2011 Estimation of future precipitation change in the Yangtze River basin by using statistical downscaling method; Stoch. Env. Res. Risk A. 25(6) 781-792.

Immerzeel W W, van Beek L P H and Bierkens M F P 2010 Climate change will affect the Asian water towers; Science 328(5984) 1382-1385, doi: 10.1126/science.1183188.

Intergovernmental Panel on Climate Change (IPCC) 2007 Climate change 2007: Impacts, adaptation and vulnerability; Contribution of Working Group II to the Fourth Assessment Report of the Intergovernmental Panel on Climate Change (eds) Parry $\mathrm{M}$ et al., Cambridge University Press, UK.

Jain S K, Goswami A and Saraf A K 2009 Assessment of snowmelt runoff using remote sensing and effect of climate change on runoff; Water Resour. Manag. 24 1763-1777.

Kattel D B and Yao T 2013 Recent temperature trends at mountain stations on the southern slope of the central Himalayas; J. Earth Syst. Sci. 122(1) 215-227.

Kendall M G 1975 Rank Correlation Methods; Charles Griffin, London.

Khan M S, Coulibaly P and Dibike Y 2006 Uncertainty analysis of statistical downscaling methods; J. Hydrol. $319357-382$.

Kim J W, Chang J T, Baker N L, Wilks D S and Gates W L 1984 The statistical problem of climate inversion: Determination of the relationship between local and large-scale climate; Mon. Wea. Rev. 112 2069-2077.

Kulkarni A, Patwardhan S, Kumar K K, Ashok K and Krishnan R 2013 Projected Climate Change in the Hindu Kush-Himalayan Region by using the High-resolution Regional Climate Model PRECIS; Mt. Res. Dev. 33(2) 142-151, doi: 10.1659/MRD-JOURNAL-D-11-00131.1.

Kulkarni A and von Storch H 1995 Monte Carlo experiments on the effect of serial correlation on the Mann-Kendall test of trend; Meteorol. Z. 4(2) 82-85.

Mahmood R and Babel M S 2013 Evaluation of SDSM developed by annual and monthly submodels for downscaling temperature and precipitation in the Jhelum basin, Pakistan and India; Theor. Appl. Climatol. 113 27-44, doi: $10.1007 /$ s00704-012-0765-0.

Mann H B 1945 Nonparametric tests against trend; Econometrica 13 245-259.

Mansell M G 1997 The effect of climate change on rainfall trends and flooding risk in the west of Scotland; Nord. Hydrol. 28 37-50.

Maurer E P and Hidalgo H G 2008 Utility of daily vs. monthly large-scale climate data: An intercomparison of two statistical downscaling methods; Hydrol. Earth Syst. Sci. 12 551-563, doi: 10.5194.

Meenu R, Rehana S and Mujumdar P P 2012 Assessment of hydrologic impacts of climate change in Tunga-Bhadra river basin, India with HEC-HMS and SDSM; Hydrol. Process., doi: 10.1002/hyp.9220. 
Mutreja K N 1986 Applied Hydrology; Tata McGraw Hill Publishing Company Limited, New Delhi.

New M, Lister D, Hulme M and Makin I 2002 A highresolution data set of surface climate over global land areas; Clim. Res. 21 1-25.

Page E S 1961 Cumulative sum charts; Technometrics 3(1) 19.

Pant G B and Rupa Kumar K 1997 Climates of South Asia: Behaviour Studies in Climatology; John Wiley and Sons, West Sussex, England, pp. 126-127.

Patra J P, Mishra A, Singh R and Raghuwanshi N S 2012 Detecting rainfall trends in twentieth century (18712006) over Orissa State, India; Clim. Change 111(3-4) 801-817.

Sen P K 1968 Estimates of the regression coefficient based on Kendall's tau; J. Am. Stat. Assoc. 631379 1389.

Shapiro G I, Aleynik D L and Mee L D 2010 Long term trends in the sea surface temperature of the Black Sea; Ocean Science 6 491-501, doi: 10.5194/os-6-491-2010.

Sharma K P, Moore B III and Vorosmarty C J 2000 Anthropogenic, climatic and hydrologic trends in the Kosi Basin, Himalaya; Clim. Change 47 141-165.

Shrestha A B, Wake C P, Mayewski P A and Dibb J E 1999 Maximum temperature trends in the Himalaya and its vicinity: An analysis based on the temperature records from Nepal for the period 1971-1994; J. Climate 12(9) 2775-2786.

Sonali P and Kumar N D 2013 Review of trend detection methods and their application to detect temperature changes in India; J. Hydrol. 476 212-227, doi: 10.1016/ j.jhydrol.2012.10.034.

Srinivas V V, Basu B, Kumar N and Jain S K 2013 Multisite downscaling of maximum and minimum temperature using support vector machine; Int. J. Climatol., doi: 01002/joc.3782.

van der Made J W 1987 Casebook of methods for computing hydrological parameters for water projects; In: A contribution to the International Hydrological Programme (ed.) Lowing M J, UNESCO, Paris.

Wilby R L and Wigley T M L 1997 Downscaling general circulation model output: A review of methods and limitations; Progr. Phys. Geogr. 21(4) 530-548.
Wilby R L and Dawson C W 2007 SDSM user manual a decision support tool for the assessment of regional climate change impacts; Available at https://copublic. lboro.ac.uk/cocwd/SDSM/main.html.

Wilby R L and Dawson C W 2013 The Statistical Down Scaling Model: Insights from one decade of application; Int. J. Climatol. 33 1707-1719, doi: 10.1002/joc.3544.

Wilby R L, Dawson C W and Barrow E M 2002 SDSM - a decision support tool for the assessment of regional climate change impacts; Environ. Model. Softw. 17 $147-159$.

Wilby R L, Hay L E, Gutowski W J, Arritt R W, Takle E S, Pan Z, Leavesley G H and Martyn P C 2000 Hydrological responses to dynamically and statistically downscaled climate model output; Geophys. Res. Lett. 27(8) 1199, doi: 10.1029/1999GL00607.

WWF Nepal Program 2005 An overview of glaciers, glacier retreat, and subsequent impacts in Nepal, India and China; http://assets.panda.org/downloads/ himalayaglaciersreport2005.pdf.

Xiangsheng Y I, Guoshen L I and Yanyu Y I N 2013 Spatiotemporal variation of precipitation in the Three-River Headwater Region from 1961 to 2010; J. Geogr. Sci. 23(3) 447-464.

$\mathrm{Xu} \mathrm{Z}$, Gong T and Liu C 2008 Decadal trends of climate in the Tibetan Plateau - regional temperature and precipitation; Hydrol. Process. 22(16) 3056-3065.

Yarnal B, Comrie A C, Frakes B and Brown D P 2001 Developments and prospects in synoptic climatology; Int. J. Climatol. 21 1923-1950.

Yue S and Pilon P 2003 Interaction between deterministic trend and autoregressive process; Water Resour. Res. 39(4), doi: 10.1029/2001WR001210.

Yue S and Wang C Y 2002 Applicability of pre-whitening to eliminate the influence of serial correlation on the Mann-Kendall test; Water Resour. Res. 38(6), doi: 10.1029/2001WR000861.

Yue S, Pilon P and Cavadias G 2002 Power of the MannKendall and Spearman's rho tests for detecting monotonic trends in hydrological series; J. Hydrol. $259254-271$.

Zhang Q, Jiang T, Gemmer M and Becker S 2005 Precipitation, temperature and runoff analysis from 1950 to 2002 in the Yangtze basin, China; Hydrol. Process. 50(1) 65-79. 